\title{
„Polak w Afryce” o młodych i najmłodszych uchodźcach polskich z ZSRR w Afryce w latach 1943-1945
}

\begin{abstract}
Abstrakt: Głównym celem artykułu jest przedstawienie tego, co i w jakiej formie o młodych i najmłodszych uchodźcach polskich z ZSRR, którzy dotarli na kontynent afrykański, pisała ukazująca się w Afryce w latach 1943-1945 polska gazeta, tj. „Polak w Afryce”. Uchodźcy ci rozlokowani byli w krajach Brytyjskiej Afryki Wschodniej (tj. w Kenii, Tanganice i Ugandzie) oraz w Rodezji Północnej i Rodezji Południowej, a także w Unii Południowej Afryki. Blisko połowę mieszkańców polskich osiedli stanowili młodzi i najmłodsi, wielokrotnie sieroty lub półsieroty, co w konsekwencji spowodowało, iż gazeta poświęcała im sporo miejsca.
\end{abstract}

Słow a kluc zowe: Polska, II wojna światowa, uchodźcy polscy z ZSRR, Afryka.

Abstract: The purpose of the article is to present what and in what form the Polish newspaper Polak $w$ Afryce (Pole in Africa) appearing in Africa in 1943-45 published about the young and youngest Polish refugees from the USSR who reached the African continent. These refugees were located in the countries of British East Africa (i.e. Kenya, Tanganyika, and Uganda), in Norther Rhodesia and Southern Rhodesia as well as in the Union of South Africa. Almost half of the inhabitants of the Polish settlements were young and the youngest children, often orphans or half-orphans, and due to this fact the Polish paper devoted a lot of space to them.

Key w ord s: Poland, Word War II, Polish refugees from the USSR, Africa.

Głównym celem prezentowanego artykułu jest przedstawienie tego, co i w jakiej formie o młodych i najmłodszych uchodźcach polskich z ZSRR, którzy dotarli na kontynent afrykański, pisała ukazująca się w Afryce w latach 1943-1945, 
w Nairobi, polska gazeta, pt. „Polak w Afryce”. Można zatem przyjać, iż jest to swego rodzaju kontynuacja tematyki podjętej swego czasu przez autora niniejszego materiału, dotyczącej wówczas Polaków w Iranie ${ }^{1}$. Tym razem w odniesieniu do dalszych losów tej ich części, która ulokowana została na kontynencie afrykańskim. Przed zaprezentowaniem tytułowego zagadnienia trzeba, osadzając materiały prasowe w ówczesnej rzeczywistości historycznej, przypomnieć kilka zasadniczych kwestii. W efekcie ewakuacji z ZSRR w $1942 \mathrm{r}$. do Iranu przybyło ponad 75 tys. wojskowych oraz blisko 40 tys. cywilów. Według raportu odpowiadającego ze strony brytyjskiej za przyjęcie Polaków, sporządzonego przez płk. Alexandra Rossa (przedstawiciela MERRA - Middle East Relief and Refugee Administration), w Iranie znalazło się 116131 Polaków. Wśród nich było blisko 20 tys. młodocianych uchodźców²

Ewakuowane z ZSRR oddziały wojskowe stosunkowo szybko zostały przesunięte na inne terytoria. Te z pierwszej ewakuacji skierowano do Palestyny, a te $\mathrm{z}$ drugiej do Iraku. W Iranie pozostała ludność cywilna, przy czym tylko dla części z nich kraj ten stał się miejscem stałego pobytu do 1945 r. ${ }^{3}$ Rzecza niemożliwą było bowiem zatrzymanie na terenie Iranu blisko 40-tysięcznej rzeszy ludności cywilnej. Stąd też konieczne stało się podjęcie działań w skali międzynarodowej zmierzających do ulokowania tych ludzi w miejscach, które dawałyby im gwarancję spokojnego dotrwania do końca wojny, a po jej zakończeniu, powrotu do Polski. Jednym z takich właśnie miejsc stała się Afryka ${ }^{4}$, do której transporty uchodźców kierowane były już w 1942 r. Do listopada tego roku ewakuowano tu ponad 11 tys. cywilów. Z czasem tempo napływu uchodźców wyraźnie zmalało.

Ostatecznie uchodźcy z ZSRR rozlokowani zostali w krajach Brytyjskiej Afryki Wschodniej (tj. w Kenii, Tanganice i Ugandzie) oraz w Rodezji Północnej i Rodezji Południowej, a także w Unii Południowej Afryki. Trzeba tu dodać, iż w Rodezji Północnej spotkali oni przybyłych tam już wcześniej, bo w 1941 r., ponad 400 Polaków, należących do tzw. grupy cypryjskiej, których tułacze drogi wiodły przez Rumunię, Cypr i Palestynę.

Ogółem w Afryce znalazło schronienie i kilkuletnią przystań ponad 18 tys. uchodźców ${ }^{5}$. Zdecydowana większość z nich ulokowana została w Brytyjskiej Afryce Wschodniej. W grudniu 1944 r. było tu 13364 Polaków, w Rodezji Północnej - 2894, a w Rodezji Południowej - 1437. Do tego dochodziło

\footnotetext{
${ }^{1}$ M. Ney-Krwawicz, „Polak $w$ Iranie” o mtodych i najmłodszych uchodźcach polskich z ZSRR $w$ Iranie $w$ latach 1942-1944, „Dzieje Najnowsze” 2014, nr 1, s. 85-110.

${ }^{2}$ Szerzej zob. J. Wróbel, Uchodźcy polscy ze Zwiazku Sowieckiego 1942-1950, Łódź 2003.

${ }^{3}$ Szerzej zob. J. Pietrzak, Polscy uchodźcy na Bliskim Wschodzie w latach drugiej wojny światowej. Ośrodki, instytucje, organizacje, Łódź 2012.

${ }^{4}$ Szerzej zob. E. Wróbel, J. Wróbel, Rozproszeni po świecie. Obozy i osiedla uchodźców polskich ze Zwiazku Sowieckiego 1942-1950, Chicago 1992; J. Wróbel, Uchodźcy..., s. 136-175; H. Zins, Polacy w Afryce Wschodniej, Lublin 1978.
}

${ }^{5}$ J. Wróbel, Uchodźcy..., s. 160. 
550 uchodźców przebywających w Unii Południowej Afryki. Najwięcej Polaków było w Tanganice (6631) oraz w Ugandzie (6443). W Kenii zaś przebywało ich tylko 290.

Generalnie uchodźcy umieszczani byli w specjalnych osiedlach, w części przypadków właśnie dla nich wybudowanych. Według stanu z grudnia 1944 r. ${ }^{6}$ Polacy znajdowali się w następujących miejscach - na terytorium Kenii: Makindu, Mombasa, Nairobi; w Ugandzie: Kampala, Koja, Masindi; w Tanganice: Dar es Salaam, Ifunda, Kidugala, Kigoma, Kondoa, Morogoro, Tengeru; w Rodezji Północnej: Abercorn, Bwana M’Kubwa, Fort Jameson, Lusaka, Katambora; w Rodezji Południowej: Digglefold, Marandellas, Rusape, Salisbury; w Unii Południowej Afryki: Oudtshoorn. Część wymienionych wyżej miejsc to ośrodki miejskie grupujące przede wszystkim pracowników polskiej administracji, jak np. w Nairobi. Należy także podkreślić, iż istniały duże dysproporcje między zaludnieniem poszczególnych osiedli i ośrodków. I tak przykładowo największe osiedle w Tanganice, Tengeru, w grudniu 1944 r. zamieszkiwało 4018 osób, zaś Kidugalę - 798, a Kigomę - tylko 188 Polaków. Natomiast największym osiedlem w Ugandzie było Masindi z 3635 mieszkańcami, gdy w tym samym czasie w Koji przebywało 2800 Polaków. W Rodezji Północnej w Bwana M’Kubwa było 1182 mieszkańców, a w Abercorn - tylko 561. W Rodezji Południowej Rusape miało 726 mieszkańców, a w Digglefold było tylko 85 Polaków.

Właściwie każde osiedle uchodźcze stawało się swego rodzaju „mała Polską" Miało swój samorząd, świetlicę, szkoły, a przydomowym obejściom starano się nadać swojski charakter. Przykładowo można tu odwołać się do najlepiej opisanego w literaturze osiedla Tengeru ${ }^{7}$.

Usytuowanie w Afryce blisko 20-tysięcznej rzeszy uchodźców wymagało rozbudowania sieci polskich placówek dyplomatycznych. W pierwszym rzędzie utworzono Konsulat Generalny w Nairobi, obejmujący poczattkowo poza Kenią także Ugandę i Tanganikę, w których z czasem powołano również nasze placówki konsularne ${ }^{8}$. Placówki takie powstały też w obu Rodezjach i w Unii Południowej Afryki. Poza placówkami dyplomatycznymi niezbędne okazało się powołanie odpowiednich struktur Ministerstwa Pracy i Opieki Społecznej (MPiOS). Ich tworzenie rozpoczął przybyły w sierpniu 1942 r. do Afryki inż. Stefan Daszyński. Już jednak we wrześniu minister Stanisław Kot skierował do inż. Kazimierza Kazimierczaka pismo, w którym poruczał mu tymczasowe kierownictwo „całej opieki nad uchodźctwem polskim w Afryce” oraz zawiadamiał, iż „Pan ponosi pełną odpowiedzialność za organizację bytu naszych uchodźców i za dobór wszystkich osób do kierownictwa Opieki

\footnotetext{
${ }^{6}$ Ibidem, s. 160, przytaczane poniżej dane liczbowe także w ślad za tą pozycja.

${ }^{7}$ Szerzej zob. A. Hejczyk, Sybiracy pod Kilimandżaro. Tengeru. Polskie osiedle w Afryce Wschodniej we wspomnieniach jego mieszkańców, Rzeszów-Kraków 2013.

8 J. Wróbel, Uchodźcy..., s. 140-142.
} 
Centralnej i obozów" na całą Brytyjską Afrykę Wschodnią oraz obie Rodezje i Unię Południowej Afryki. Z czasem koniecznościa stało się jednak utworzenie placówek MPiOS w Ugandzie i Tanganice oraz Rodezji. Poza MPiOS swoje delegatury powołało też Ministerstwo Skarbu i Najwyższa Izba Kontroli. Zagadnienia szkolnictwa początkowo koncentrowały się w Delegaturze MPiOS w Nairobi. Ona także powołała Referaty Oświatowe w poszczególnych osiedlach uchodźczych. Z czasem utworzono Delegaturę Ministerstwa Wyznań Religijnych i Oświecenia Publicznego (MWRiOP) z uprawnieniami kuratorium szkolnego ${ }^{10}$.

Sygnalizując zasadnicze kwestie związane z rozlokowaniem uchodźców w Afryce, trzeba koniecznie podkreślić zarówno to, iż osiedla polskie były oddalone od siebie już nie tylko o setki, ale i tysiące kilometrów, jak również i to, że położone były, jak już pisano, w kilku krajach. Wpływało to na wzajemne ich kontakty i możliwości przepływu informacji.

$\mathrm{W}$ tej sytuacji ogromna rola przypadła polskiej prasie. Mówiąc nieco publicystycznie, można stwierdzić, iż wszędzie tam, gdzie zaistniały w czasie wojny polskie skupiska, nieodłącznym ich elementem stawała się polska prasa. Nie inaczej było i w Afryce. Biorąc pod uwagę zarówno liczebność, jak i rozrzut terytorialny uchodźczych osiedli, koniecznością stało się wydawanie przeznaczonej dla nich polskiej gazety, która informowałaby zarówno o ogólnych kwestiach związanych z przebiegiem wojny, stanowisku Rządu $\mathrm{RP}$, jak i o tym, co dzieje się $\mathrm{w}$ tak oddalonych od siebie osiedlach. Innymi słowy, która byłaby zarówno przekaźnikiem ważnych z polskiego punktu widzenia informacji, jak i łącznikiem między polskimi skupiskami. Tak też usytuowana w Nairobi Delegatura MPiOS zaczęła w 1943 r. drukowanie pisma „Polak w Afryce”. Na marginesie trzeba zauważyć, iż było ono jednym z kilku pism wydawanych przez działające $\mathrm{w}$ różnych krajach delegatury MPiOS. I tak w Iranie ukazywał się od 1942 r. „Polak w Iranie”, w Indiach od 1943 r. „Polak w Indiach”, a w Meksyku „Polak w Meksyku”.

14 III 1943 r. ukazał się pierwszy numer pisma „Polak w Afryce”, którego podtytuł głosił, iż jest to „Dwutygodnik poświęcony sprawom uchodztwa polskiego w Afryce wydawany przez Delegaturę Min. P. i O.S. w Nairobi”. Na zakończenie słowa „Od redakcji” w tym pierwszym numerze pisano m.in.: „Drodzy! Pismo nasze ma być pomostem pomiędzy wami a wszystkim co polskie, ma być jedynym niemal słowem polskim, które was będzie regularnie dochodziło i łączyło ze światem. Chcielibyśmy, żeby stało się ono waszym przyjacielem, waszym doradca, waszym powiernikiem. Piszcie do nas,

${ }^{9}$ Cyt. za: M. Ney-Krwawicz, Na pięciu kontynentach. Polskie dzieci, młodziė̇ $i$ szkoty na tułaczych szlakach 1939-1950, Warszawa 2014, s. 150.

${ }^{10}$ Szerzej zob. W. Chmielewski, Powstanie delegatur polskiej administracji szkolnej na uchodźstwie, „Rozprawy z Dziejów Oświaty” 2012, t. XLIX s. 35-53; idem, Polska administracja szkolna w latach 1944-1950, Piotrków Trybunalski 2010. 
o tym co was cieszy i co was boli, o waszych nadziejach, obawach i życzeniach. Będziemy się starali pomóc wam i poradzić, jak możemy"11. Trzeba tu dodać, iż jak zaznaczała sama redakcja, „Nie mogac dostac polskich czcionek musielismy ropoczac druk gazety uzywajac czcionek alfabetu lacinskiego. Natychmiast po otrzymaniu zamowionych czcionek przejdziemy na alfabet polski. Tymczasem prosimy czytelnikow o wybaczenie"12. Z analogicznymi trudnościami borykała się także redakcja „Polaka w Iranie”. Brak polskich czcionek odbijał się na czytelności pisma poprzez np. zniekształcanie pisowni nazwisk czy nazw, co jednak nie stanowiło specjalnej trudności dla odbiorców. Trzeba bowiem podkreślić, iż dla uchodźców najważniejsze było to, że gazetę wydawano w języku polskim. Otaczający ich świat porozumiewał się $\mathrm{w}$ albo całkowicie nieznanych im narzeczach lokalnych, albo w znanym tylko bardzo nielicznym języku angielskim. Do osiedli zaczęły docierać wprawdzie z czasem takie polskie pisma, jak „Orzeł Biały” czy „Parada”, ale zawarte w nich materiały prasowe dotyczyły bardzo odległych kwestii, aczkolwiek stawały się ważnym nośnikiem informacji o sprawach polskich w tamtym czasie. W kontekście informacyjnej roli prasy trzeba jeszcze zwrócić uwage i na to, iż od 4 III 1943 r. radiostacja brytyjska w Nairobi zaczęła nadawanie trzy razy w tygodniu 15-minutowych audycji w języku polskim. Część osiedli została zaopatrzona w odbiorniki radiowe ${ }^{13}$. Czym innym jednak była 15-minutowa audycja, czym innym zaś kilkustronicowa gazeta, do której można było wielokrotnie powracać. Objętość „Polaka w Afryce” wahała się przeważnie od 4 do 8 stron. Pismo było ilustrowane fotografiami dopełniającymi materiał tekstowy. Z czasem gazetę drukowano już z użyciem polskich czcionek. Od 15 VI 1943 r. pismo ukazywało się co tydzień i miało podtytuł „Tygodnik poświęcony..."14 Od stycznia 1945 r. w stopce wydawniczej poza wydawca (Delegaturą MOS) umieszczono informację: „Redakcja: Pl. Centrum Informacji Nairobi PO Box 1939"15. Funkcję redaktora objął Janusz Knake, który sam także zasilał gazetę swoimi tekstami.

Zgodnie z przyjętymi założeniami „Polak w Afryce” był pismem o charakterze przede wszystkim informacyjnym, przeznaczonym dla szerokiego kręu odbiorców mieszkajacych w osiedlach uchodźczych. Podawane informacje z życia osiedli miały przeważnie dwu- lub trzytygodniowe, a nawet miesięczne, opóźnienie w stosunku do zaistnienia danego zdarzenia. Zważywszy na tempo życia w osiedlach oraz to, iż pismo było tygodnikiem, nie stanowiło to jednak większego problemu dla odbiorców. Dla nich najistotniejsze było, iż mogli, nawet z pewnym opóźnieniem, dowiedzieć się, co dzieje się w innych

\footnotetext{
11 „Polak w Afryce” 1943, nr 1, s. 2.

12 Poza wyjątkiem w tym przykładzie autor $\mathrm{w}$ cytatach stosuje zapis z polskimi czcionkami dla większej czytelności tekstu.

13 „Polak w Afryce” 1943, nr 1, s. 4.

14 „Polak w Afryce” 1943, nr 7, s. 1.

15 „Polak w Afryce” 1945, nr 1-2, s. 8.
} 
osiedlach, jak tam rozwija się szkolnictwo, harcerstwo, jak przebiegały obchody różnych świąt i rocznic, jakie podejmowano inicjatywy. Źródłem informacji dla redakcji były m.in. nadsyłane listy do redakcji, a także korespondencje wysłanników. Biorąc pod uwagę główny wątek niniejszego artykułu, trzeba podkreślić, iż blisko połowę mieszkańców tychże osiedli stanowili młodzi i najmłodsi uchodźcy, wielokrotnie sieroty lub półsieroty. Przywołując dane liczbowe z grudnia 1944 r.: w Ugandzie dzieci i młodzież to $45 \%$ uchodźców, w Tanganice - 40,8\%, w Rodezji Północnej było to 39,8\%, a w Rodezji Południowej - 43,2\% ${ }^{16}$. Rzecz jasna, iż owe wskaźniki różnie wyglądały w poszczególnych osiedlach. I tak np. w Masindi młodzi i najmłodsi mieszkańcy stanowili aż 48,4\%, w Marandellas - 48,5\%, w Bwana M'Kubwa $44,2 \%$, w Tengeru $-43 \%$, w Ifundzie - 40,1\%, ale już w Kigomie było to $15,4 \%$. Generalnie jednak odsetek dzieci i młodzieży oscylował w osiedlach w okolicach $40 \%$ ich mieszkańców.

Tak duża liczba młodych i najmłodszych uchodźców niosła z sobą rozliczne konsekwencje. Przede wszystkim był to bardzo dynamiczny rozwój szkolnictwa szczebla powszechnego i średniego ${ }^{17}$. Inna pochodna tej sytuacji stał się także bardzo dynamiczny rozwój struktur harcerskich obejmujących wszystkie osiedla ${ }^{18}$. Fakt, iż część dzieci stanowiły sieroty, spowodował też tworzenie dla nich sierocińców. Bardzo specyficznym miejscem był w tym względzie Oudtshoorn, w którym na 500 młodych uchodźców 183 to pełne sieroty, a 204 to półsieroty ${ }^{19}$.

Taka struktura wiekowa społeczności uchodźczej nie mogła pozostać bez wpływu na zawartość jedynego redagowanego i wydawanego na tym terenie pisma, obejmującego swoim zasięgiem oddziaływania (a jednocześnie i zakresem podawanych informacji) wszystkie polskie ośrodki. Tym samym tematyka związana z młodymi i najmłodszymi uchodźcami, w różnych aspektach, stawała się poniekąd czymś naturalnym zarówno dla redakcji pisma, jak i jego odbiorców. Tak też młodzi i najmłodsi uchodźcy z jednej strony stawali się obiektem, o którym pisano w „Polaku w Afryce”, z drugiej zaś strony byli jego odbiorcami i czytelnikami.

Już w pierwszym numerze „Polaka w Afryce” na stronie 7 pojawił się niewielki „Kącik dla młodzieży” ${ }^{20}$. Zamieszczono w nim wiersz Józefa Czechowicza Marzenie o marzeniu młodego człowieka, aby zostać lotnikiem oraz

\footnotetext{
${ }^{16}$ J. Wróbel, Uchodźcy..., s. 160.

17 Szerzej zob. W. Chmielewski, Szkolnictwo polskie w Afryce Środkowo-Wschodniej i Południowej podczas II wojny światowej, „Przegląd Historyczno-Oświatowy” 2008, nr 3-4, s. 61-74.

${ }^{18}$ Szerzej zob. B.M. Pancewicz, Harcerstwo $w$ Afryce 1941-1949, Londyn 1985; Polskie sybiraczki harcerki w Afryce 1942-1950, oprac. H. Dabkowski, Warszawa 2002.

${ }^{19}$ Szerzej zob. J. Wróbel, Z Syberii na Antypody. Osiedle polskich sierot $w$ Oudtshoorn 1943-1950, w: Wokót spraw trudnych, bolesnych i zapomnianych. Studia i szkice, red. E. Kowalczyk, L. Ladorucka, W. Marciniak, B. Szubtarska, J. Żelazko, Łódź 2014, s. 863-907. 20 „Polak w Afryce” 1943, nr 1, s. 7.
} 
artykuł Drzewa gumowe poświęcony uprawie i wykorzystaniu drzew, z których produkowano gumę, a także produkcji sztucznej gumy. W końcowej części artykułu pisano: „Będzie wam przyjemnie dowiedzieć się, że polscy chemicy również wynaleźli sposób fabrykacji sztucznej gumy", podkreślając, iż guma ta była lepsza od sztucznej gumy wynalezionej przez niemieckich chemików. Nietrudno odgadnać przesłanie owego niewielkiego materiału, który miał w rzuconych w dalekie strony młodych uchodźcach wzbudzać dumę z polskich dokonań. „Kącik dla młodzieży” w takiej formule nie zaistniał już więcej.

Natomiast od numeru 2 pojawił się za to „Płomyczek Afrykański” ${ }^{1}$ ukierunkowany ku młodszym oraz najmłodszym odbiorcom. Jego znaczenie wykraczało znacznie poza zwykły „kącik” dla dzieci i młodzieży gimnazjalnej. W sytuacji uchodźców odczuwających głód polskiej książki, w tym i tej dla najmłodszych, „Płomyczek Afrykański” stał się nie tylko skierowanym ku nim polskim słowem drukowanym, ale przede wszystkim pomoca dydaktyczna w nauczaniu czytania. Wprawdzie, jak to już pisano, brak polskich czcionek dawał się we znaki, jak np. w tytule $O$ sloniu $i$ jego trabie, to wobec braku polskiej książki i tak było to już bardzo dużo. W tym też numerze zamieszczono apel Do czytelników Płomyczka Afrykańskiego o nadsyłanie do niego listów „z zapytaniami o rzeczach, które was interesuja” oraz opisów wrażeń, przygód, a także tego, co młodych czytelników najbardziej zaciekawia w otaczającym ich kraju.

Należy tu zwrócić uwagę na fakt, iż początkowo „Płomyczek Afrykański”, opatrzony charakterystyczną winietą ze słoniem, książka, żyrafą i strusiami, stanowił integralna część „Polaka w Afryce”, zajmując albo całą, albo prawie całą stronę przy końcu numeru. W numerze 9 pojawiła się zapowiedź, iż „«Płomyczek Afrykański» od następnego numeru «Polaka w Afryce» będzie wydzielony jako odrębne pisemko, ukazujące się w odstępach dwutygodniowych" ${ }^{22}$. I tak też się stało. „Płomyczek Afrykański” zaczął wychodzić w formie samoistnego druku, o objętości czterech stron, w mniejszym jednak formacie niż „Polak w Afryce". Poczatkowo zrezygnowano z ilustrowanej winiety, ale z czasem powrócono do niej, zachowując ją do 1945 r. Każdy numer miał swoją ciagła numerację. Trzeba tu jeszcze dodać, iż od samego początku „Płomyczek” był ilustrowany rysunkami związanymi z zamieszczanymi w nim tekstami. Ostatni „Płomyczek” (nr 40) w formie samoistnego dodatku ukazał się 25 I 1945 r. Od numeru 41 „Płomyczek” powrócił do swojej pierwotnej formy, czyli jednej strony w „Polaku w Afryce” (z zachowaniem numeracji, aczkolwiek ostatnie nie były już numerowane). I tak ukazywał się do końca wydawania pisma.

Zamieszczony w pierwszym „Płomyczku” apel o nadsyłanie listów nie pozostał bez echa. Już w numerze 4-5 „Polaka w Afryce” opublikowano dwa listy Do „Płomyczka Afrykańskiego”. W przypadku drukowanych przez różne

21 „Polak w Afryce” 1943, nr 2, s. 7-8.

22 „Polak w Afryce” 1943, nr 9, s. 4. 
redakcje „listów do redakcji” nigdy nie ma pewności, że owe listy istotnie „nadeszły” do redakcji, a nie były napisane przez samych redaktorów w celu poruszenia jakichś tematów. Tu jednak, biorąc pod uwagę podpisanie listów przez konkretne klasy szkół powszechnych (a nie enigmatycznych „czytelników”), można sądzić, iż istotnie zostały przez owe klasy napisane, aczkolwiek niewątpliwie ostateczny kształt nadały im panie nauczycielki. Jeden list był od uczniów szkoły w Tengeru, drugi od uczniów z Koja. Uczniowie z Tengeru pisząc o braku polskich książek i podręczników, podsuwali redakcji pomysł: „nasza klasa z panią na czele uchwaliła następujący projekt: przepisać kilka ładnych czytanek i posłać je do Redakcji Płomyczka i prosić bardzo o przedrukowanie ich w gazecie, gdyż gazetę może kupić każdy z nas. Wtedy wszystkie klasy będą mogły się nauczyć czytać. Prosimy Cię "Płomyczku Afrykański» racz uwzględnić naszą prośbę a będziemy $\mathrm{Ci}$ bardzo wdzięczni” ${ }^{23}$. Z kolei uczniowie z Koja pisali: „Wielką usługę gazetka oddaje nam w szkole - nasza Pani Wychowawczyni, zapowiedziała, żebyśmy przynosili gazetkę na lekcje języka polskiego. Podręczników szkolnych nie mamy, więc czytamy śliczne opowiadania i wierszyki z gazety. My szkolne dzieci mamy świetna pomoc z tej gazetki" ${ }^{24}$. Bez względu na to, czy inspiracja do tych listów wyszła od dzieci, czy od nauczycieli, poruszały one kapitalnej wagi problem - rolę „Płomyczka Afrykańskiego” i szerzej „Polaka w Afryce” w procesie dydaktycznym przy braku książek i podręczników. Oba te listy z jednej strony zapewne utwierdziły redakcję $\mathrm{w}$ słuszności wydawania pisemka dla młodych, z drugiej zaś strony miały swoje konsekwencje w niezbyt odległej przyszłości.

Publikowane w „Płomyczku” teksty miały służyć zarówno nauce, jak i wychowaniu młodego pokolenia. Zamieszczano w nim więc bajki i opowiadania o charakterze dydaktycznym. Na przykład w numerze 2 „Polaka w Afryce" była to bajka Żótw i jaszczurka o chytrej jaszczurce, która ukradła żółwiowi worek soli, twierdząc, że go znalazła, a rzecz znaleziona należy do znalazcy, i o karze, jaka ją za to spotkała. Niektóre teksty przestrzegały $\mathrm{w}$ formie opowiastki przed niebezpieczeństwami ze strony otaczającej przyrody, jak np. Krokodyl $i$ jego dentysta ${ }^{25}$ z morałem: „Nie ufaj krokodylowi nawet jeżeli stracił wszystkie swoje zęby”. Często także ogłaszano przekłady na język polski różnych bajek angielskich, jak np. Bajka o złym ludożercy $i$ niepostusznym Tomku ${ }^{26}$, który po przygodzie z ludożerca „stał się bardzo grzecznym i posłusznym i zawsze słuchał mamusi”. Była też Bajka o odważnym $\dot{z}$ otnierzyku ${ }^{27}$ walczącym z potworem. Nie zabrakło i baśni Hansa Christiana Andersena, jak np. Historia roku ${ }^{28}$.

\footnotetext{
${ }^{23}$ „Polak w Afryce” 1943, nr 4-5, s. 12.

${ }^{24}$ Ibidem, s. 12.

25 „Polak w Afryce” 1943, nr 3, s. 8.

26 „Płomyczek Afrykański” 1944, nr 27.

27 „Płomyczek Afrykański” 1944, nr 37, 38.

28 „Płomyczek Afrykański” 1944, nr 39; 1945, nr 40.
} 
W „Płomyczku” publikowano także poezję, jak np. Ignacego Krasickiego (Madry i głupi, Lew i zwierzęta ${ }^{29}$, Ptaszki $w$ klatce ${ }^{30}$ ), Adama Mickiewicza (Powrót taty ${ }^{31}$, Pani Twardowska ${ }^{32}$ ), Jana Lechonia (Historia o jednym chłopczyku i o jednym lotniku ${ }^{33}$ ), Marii Konopnickiej (Szkolne przygody Pimpusia Sadetko ${ }^{34}$ ), Juliusza Słowackiego (W pamiętniku Zofii Bobrówny ${ }^{35}$ ), Mariana Hemara (Pisanki $\left.{ }^{36}\right)$.

Nie zabrakło w „Płomyczku” i prozy wpisanej w dzieje polskiej literatury publikowanej pod kątem lekcji języka polskiego lub historii, jak np. Jana Chryzostoma Paska (Wydra Króla Jana ${ }^{37}$ ) lub Stefana Żeromskiego (Śmierć Żótkiewskiego $\left.{ }^{38}\right)$.

„Płomyczek” zaznajamiał także czytelników z legendami i podaniami Czarnego Lądu, jak np. z Legendq o matym czerwonym ptaszku Kasanke ${ }^{39}$ lub O kowalu Walukaga z książki A. Kagwy Legendy Ugandy, bajką murzyńska Jak kanarek zostat królem lasu ${ }^{40}$ czy Gtupi zajac ${ }^{41}$ (z serii Legendy Ugandy). Zamieszczano też teksty mówiące o przyrodzie, jak np. Ptaki Wschodniej Afryki ${ }^{42}$ St. Zdanowicza.

Nieraz na łamach „Płomyczka” pojawiały się teksty poświęcone walce o niepodległość i w tym kontekście zaangażowaniu w nią młodzieży. I tak np. 2 VI 1943 r. zamieszczono tekst pt. Bolek o kolportażu przez młodego warszawiaka sfingowanego przez podziemie nadzwyczajnego dodatku do „Nowego Kuriera Warszawskiego” z prawdziwymi wiadomościami o przebiegu wojny ${ }^{43}$. Godzi się tu podkreślić, iż faktycznie wydarzenie takie miało miejsce w Warszawie w niedzielę 21 III 1943 r., a więc zaledwie niecałe dwa miesiące wcześniej. Innym tekstem był np. ten $O$ matym kolporterze ${ }^{44}$ opisujący Janka kolportującego podziemną prasę z zaznaczeniem, iż „Za wydawanie, sprzedawanie i czytanie tych pism grozi Polakom śmierć lub więzienie". Bohater $z$ pod Narwiku ${ }^{45}$ to z kolei tekst o młodocianym żołnierzu

\footnotetext{
29 „Polak w Afryce” 1943, nr 4-5, s. 10, 12.

„Polak w Afryce” 1943, nr 6, s. 8.

${ }^{1}$ „Polak w Afryce” 1943, nr 9, s. 4.

32 „Płomyczek Afrykański” [1943], nr 11.

33 „Płomyczek Afrykański” [1943], nr 17.

34 „Płomyczek Afrykański” 1944, nr 19, 20, 21.

35 „Płomyczek Afrykański” 1944, nr 32.

36 „Płomyczek Afrykański” 1945, nr 43.

37 „Polak w Afryce” 1943, nr 4-5, s. 10.

38 „Płomyczek Afrykański” [1943], nr 10.

39 „Płomyczek Afrykański” [1943], nr 14.

40 „Płomyczek Afrykański” 1944, nr 19.

${ }^{41}$ „Płomyczek Afrykański” 1944, nr 20.

42 „Płomyczek Afrykański” 1944, nr 31.

43 J.K, Bolek, „Polak w Afryce” 1943, nr 6, s. 7.

44 „Płomyczek Afrykański” 1944, nr 22.

45 „Płomyczek Afrykański” [1943], nr 14.
} 
Samodzielnej Brygady Strzelców Podhalańskich odznaczonym Orderem Virtuti Militari. Powstanie Warszawskie, obszernie relacjonowane na łamach „Polaka w Afryce”, wpłynęło na poświecenie jednego numeru „Płomyczka” (nr 33 z 8 IX 1944 r.) w całości Warszawie i jej mieszkańcom. Numer otwierał tekst pieśni żołnierzy Armii Krajowej Naprzód do boju żotnierze... Zamieszczono też materiał o warszawskim ZOO oraz kolejny odcinek Legend warszawskich Artura Oppmana i wiersz M. Konopnickiej Warszawie ${ }^{46}$.

Historię przybliżano poprzez materiały przede wszystkim w formie legend i podań, jak np. Legenda o białym orle ${ }^{47}$, o tym, jak Orzeł Biały stał się godłem Polski. Innym przykładem mogą być ogłaszane w wielu numerach Legendy warszawskie $^{48}$ A. Oppmana.

Na łamach „Płomyczka” znalazła swoje odbicie akcja pisania przez dzieci i młodzież listów do polskich żołnierzy będących na froncie. Akcja ta obejmowała nie tylko skupiska w Afryce, ale także w Indiach, Iranie, Palestynie. Polegała na utrzymywaniu przez dzieci i młodzież kontaktu korespondencyjnego z żołnierzami, co dawało obopólne korzyści, gdyż każda ze stron mogła poczuć się mniej samotna. W listopadowym numerze „Płomyczka" z 1944 r. opublikowano obszerny list żołnierzy 2 Korpusu Polskiego do dzieci polskich z osiedla Bwana M'Kubwa ${ }^{49}$, z apelem: „Nie zapominajcie o nas żołnierzach, zawsze znajdziemy chwilkę czasu, aby wam na wasze listy odpowiedzieć” ${ }^{50}$.

Uczniowie szkół z afrykańskich osiedli mogli także przeczytać w „Płomyczku” o swoich rówieśnikach z innych polskich szkół na obczyźnie, jak np. w materiale Nasi najmłodsi żotnierze. Z życia Junaków na Śrrodkowym] Wschodzie $e^{51}$ przedstawiajacym m.in. Junacką Szkołę Kadetów.

W „Płomyczku” zamieszczono również przedruk artykułu Sabiny Dmuchowskiej, uczennicy IV klasy gimnazjum, z jednodniówki uczennic gimnazjum w Digglefold w Rodezji Południowej, pt. Nasza szkota ${ }^{52}$, przytaczając też, w ślad za jednodniówka, nieco informacji o tym ośrodku szkolnym.

Nie zabrakło również i korespondujących z materiałami prasowymi zamieszczanymi w „Polaku w Afryce” tekstów odnoszących się do kwestii zdrowia i higieny. I tak np. opublikowano tekst Malaria - nasz najgorszy wróg ${ }^{53}$ stanowiący nadesłane z Masindi wypracowanie Kazimierza Cybulskiego, ucznia IV klasy tamtejszego gimnazjum, w którym opisywał on zasady postępowania,

\footnotetext{
${ }^{46}$ „Płomyczek Afrykański” 1944, nr 33.

47 „Płomyczek Afrykański” 1944, nr 24.

48 „Płomyczek Afrykański” 1944, nr 27-39; 1945, nr 40-45 (w tym nr 44 mylnie oznaczono jako 42).

49 „Płomyczek Afrykański” 1944, nr 37.

${ }^{50}$ Ibidem.

51 „Płomyczek Afrykański” 1944, nr 22, 23.

52 „Płomyczek Afrykański” 1944, nr 35.

53 „Płomyczek Afrykański” 1944, nr 21.
} 
dzięki którym można uniknać zachorowania na malarię. Natomiast tekst Dlaczego?... Dlatego... ${ }^{54}$ z ostatniego „Płomyczka” kończył się następująco: „A jak wam się zdaje - co uczyniło nas zdrowszymi i silniejszymi? Wodociag, mydło i czysto wyprana koszula".

W numerze 27 z 28 V 1944 r. ogłoszono pierwszy konkurs „Płomyczka Afrykańskiego" pt. Poznajemy Afrykę $e^{55}$. Trzy najlepsze prace zawierające opis wycieczki ze swego osiedla miały zostać opublikowane na łamach pisma. W numerze 32 z 17 sierpnia ogłoszono werdykt redakcji o przyznaniu dwóch drugich nagród, tj. dla Leszka Kłoska, ucznia I klasy Polskiego Gimnazjum Państwowego w Livingstone (za opis wycieczki z obozu Oudtshoorn do grot) oraz Ryszarda Rymarskiego z tej samej klasy i szkoły (za opis wycieczki do Victoria Falls) ${ }^{56}$.

Nie zabrakło w „Płomyczku” i odniesień do harcerstwa, jakkolwiek tematyka harcerska bardzo często gościła na łamach „Polaka w Afryce”, co niejako zwalniało redakcje z szerszego prezentowania tych zagadnień. I tak np. Z. Wójcikówna, organizatorka harcerstwa w Afryce, ogłosiła Gawędę $o$ św. Jerzym ${ }^{57}$, tj. patronie harcerstwa.

Święta Bożego Narodzenia 1944 r. były okazją do złożenia przez redakcję życzeń: „spełnienia naszych najgorętszych na obczyźnie marzeń - jak najszybszego powrotu do Wolnej i Niepodległej Ojczyzny, postępów w nauce, zdrowia i szczęśliwego nowego Roku, oby ostatniego na uchodźctwie" ${ }^{58}$. W numerze 42 „Płomyczka” redakcja, po nakreśleniu sytuacji Polski w marcu 1945 r., złożyła dzieciom kolejne życzenia: „W dniu Zmartwychwstania Pańskiego życzymy wam, abyście starali się jak najsilniej nad soba pracować, życzymy Wam postępów w nauce i abyście wyrośli na dzielnych obywateli Rzeczypospolitej - takich jakich ona bardzo będzie potrzebowała" ${ }^{59}$.

Jak wskazuje powyższy przegląd, „Płomyczek” stanowił ważny element procesu dydaktycznego i wychowawczego w „szkołach pod Baobabem”. Był nie tylko uzupełnieniem treści podręczników szkolnych, ale w początkowym okresie wręcz je zastępował.

Brakowi podręczników do nauki języka polskiego i historii starano się zaradzić także w inny sposób. Biorąc pod uwagę ogólne zapotrzebowanie na polskie książki i polskie słowo pisane, zaczęto wydawać jako dwutygodniowy dodatek do „Polaka w Afryce” już w 1943 r. „Książkę Polską na Uchodźctwie”, w której zamieszczano utwory z polskiej literatury. Była to kontynuacja działu „Literatura Polska”, rozpoczętego w podwójnym 4 i 5 numerze pisma. Początkowo (tak jak i „Płomyczek Afrykański”) była to integralna część pisma,

\footnotetext{
54 „Płomyczek Afrykański” [b.r.; b.nr]; „Polak w Afryce” 1945, nr 19, s. 6.

${ }_{55}$ „Płomyczek Afrykański” 1944, nr 27.

56 „Płomyczek Afrykański” 1944, nr 32.

57 „Płomyczek Afrykański” 1944, nr 27.

58 „Płomyczek Afrykański” 1944, nr 39.

59 „Płomyczek Afrykański” 1945, nr 42.
} 
a z czasem już samoistny dodatek z np. fragmentami epilogu Pana Tadeusza ${ }^{60}$ czy Sonetów krymskich ${ }^{61}$ A. Mickiewicza. W numerze 25 „Polaka w Afryce” z 10 XI 1943 r. opublikowano specjalny komunikat, w którym pisano m.in. o „Książce Polskiej na Uchodźctwie” co następuje:

[...] począwszy od numeru 9-tego będzie oddana całkowicie do użytku szkolnictwa we Wschodniej i Południowej Afryce. W dodatku tym, który nie zmienia tytułu będą ukazywały się materiały związane z programem szkolnym. Część dodatku będzie poświęcona klasom niższym. Pieczę nad doborem materiału i jego układem objął z polecenia Delegata Ministerstwa Wyznań Religijnych i Oświecenia Publicznego pana Seweryna Szczepańskiego - inspektor szkolny pan. Chruściel ${ }^{62}$.

I jakkolwiek założenie to było realizowane od wskazanego numeru 9, to dopiero w numerze 12 z 24 XII 1943 r. pojawiła się w podtytule informacja, iż jest to wydawnictwo Delegatury MWRiOP ${ }^{63}$.

W „Książce Polskiej na Uchodźctwie” zamieszczano fragmenty dzieł naszej literatury pod katem ich omawiania na lekcjach języka polskiego. I tak były to np. fragmenty Chłopów Władysława Stanisława Reymonta („Dzień Zaduszny” ${ }^{44}$, „Zima” ${ }^{65}$ ) czy Wiernej rzeki ${ }^{66}$ S. Żeromskiego, lub z Na skalnym Podhalu Kazimierza Przerwy-Tetmajera („Gazda Halny”67), wyjątki z Placówki ${ }^{68}$ Bolesław Prusa. Publikowano też materiały przydatne w nauczaniu historii, jak np. Orlęta ${ }^{69}$ o obronie Lwowa w 1918 r. lub fragmenty książki Wandy Dynowskiej Polska w zwyczaju $i$ obyczaju ${ }^{70}$.

Niektóre numery miały jednorodna tematykę, przybliżając odbiorcom albo jakiś region Polski, albo zwyczaje związane z różnymi świętami, lub znana postać. I tak np. datowany na 24 XII 1943 r. numer w całości poświęcono świętom Bożego Narodzenia (m.in. z tekstem Wigilia na obczyźnie ${ }^{71}$ Józefa Ignacego Kraszewskiego i wierszem $W$ noc wigilijna Jana Kasprowicza), z kolei inny numer Tatrom (z utworami K. Przerwy-Tetmajera i Legenda o powstaniu Tatr ${ }^{72}$ Władysława Orkana), jeszcze inne polskiemu morzu ${ }^{73}$ czy

\footnotetext{
60 „Książka Polska na Uchodźctwie” 1943, nr 7.

61 „Książka Polska na Uchodźctwie” 1943, nr 8.

62 „Polak w Afryce” 1943, nr 25, s. 1.

63 „Książka Polska na Uchodźctwie” 1943, nr 12.

64 „Książka Polska na Uchodźctwie” 1943, nr 9.

65 „Książka Polska na Uchodźctwie” 1943, nr 11.

66 „Książka Polska na Uchodźctwie” 1944, nr 14.

67 „Książka Polska na Uchodźctwie” 1944, nr 15.

68 „Książka Polska na Uchodźctwie” 1944, nr 29.

${ }^{69}$ „Książka Polska na Uchodźctwie” 1943, nr 10.

70 „Książka Polska na Uchodźctwie” 1943, nr 11.

${ }^{71}$ „Książka Polska na Uchodźctwie” 1943, nr 12.

72 „Książka Polska na Uchodźctwie” 1944, nr 15.

73 „Książka Polska na Uchodźctwie” 1944, nr 17.
} 
Wielkopolsce (z opisem wydarzeń we Wrześni w 1901 r. i Wozem Drzymały ${ }^{74}$ Józefa Weyssenhoffa). Jeden z numerów poświęcono Krakowowi (z opisem miasta i Przysięga Kościuszki ${ }^{75}$ W.S. Reymonta, legendzie o dzwonie Zygmunt). Inny zaś numer w całości mówił o Marii Skłodowskiej-Curie ${ }^{76}$.

„Książka Polska...” była też forum, na którym delegat MWRiOP składał dzieciom i nauczycielstwu szkół polskich w Afryce „najlepsze życzenia świąteczne i noworoczne”77. „Książka Polska na Uchodźctwie” stanowiła więc bardzo cenne uzupełnienie i była istotna pomoca dla nauczycieli w procesie nauczania i to zarówno języka polskiego, jak i historii.

Jak już zaznaczono, fakt, iż blisko połowę mieszkańców różnych osiedli stanowili młodzi i najmłodsi uchodźcy, odcisną swój ślad na zawartości informacyjnej „Polaka w Afryce”. Praktycznie prawie w każdym numerze, choć w różnej formie i objętości, ale pojawiała się jakaś informacja o młodym pokoleniu, które obecne było w codzienności uchodźczej w wielu aspektach. Przede wszystkim było to bardzo rozbudowane szkolnictwo obejmujące szczeble szkoły powszechnej i średniej, przy zaistnieniu też szkolnictwa typu zawodowego.

Już w pierwszym numerze „Polaka w Afryce” znalazło się odniesienie do tej sfery życia. W otwierajacym numer wystapieniu, Delegat Min. P. i O.S. do ludności polskiej w Afryce Wschodniej, inż. Kazimierz Kazimierczak stwierdzał: „Rozwijamy szkolnictwo, aby dzieci wasze mogły odrobić stracone lata nauki i rozwijać się umysłowo na pożytek Odrodzonej Ojczyzny i własny"78. Jak wiemy, „Polak w Afryce” zaczął ukazywać się kilka miesięcy po przybyciu do Brytyjskiej Afryki Wschodniej pierwszych transportów uchodźców. Od samego też początku zaczęło funkcjonować szkolnictwo, którego podwaliny położono jeszcze w Iranie, tak organizując transporty, aby mogły w nich wyjeżdżać zwarte zespoły klas szkolnych wraz z nauczycielami. Pozwalało to na szybkie uruchomienie nauki w nowych miejscach pobytu, w osiedlach.

Jak trafnie zauważono w materiale prasowym bilansujacym pierwszych osiem miesięcy pobytu w Afryce, „[...] przeszło połowę naszego uchodźctwa we Wschodniej Afryce stanowią dzieci. Nie będzie wcale przesada, jeżeli powiemy, że w wielkim stopniu one nadaja charakter naszemu uchodźctwu. One to w największym stopniu reprezentują nie dające się zgnębić żadnymi przejściami siły naszego narodu"79.

Od pierwszego numeru w „Polaku w Afryce” zaistniał stały, aczkolwiek zróżnicowany pod względem objętości, dział omawiający życie w osiedlach, w którym bardzo często podawano informacje o szkolnictwie. Już więc

\footnotetext{
74 „Książka Polska na Uchodźctwie” 1944, nr 20.

75 „Książka Polska na Uchodźctwie” 1944, nr 21.

76 „Książka Polska na Uchodźctwie” 1944, nr 24.

77 „Książka Polska na Uchodźctwie” 1943, nr 12.

78 „Polak w Afryce” 1943, nr 1, s. 1.

${ }^{79}$ Kn., Przed bilansem ośmiu miesięcy, „Polak w Afryce” 1943, nr 6, s. 1.
} 
w pierwszej edycji tego działu znalazły się skondensowane informacje (z podaniem liczby dzieci i typów szkół) pod ogólnym hasłem „Szkolnictwo w osiedlach” z Tengeru, Kondoa, Kidugala, Masindi i Koja, odnotowując niejako „punkt wyjścia” w tej dziedzinie życia. Zwrócono uwagę m.in. na warunki pracy szkół, podając, iż np. w Masindi tymczasowe pomieszczenia szkolne usytuowano w „dość przestronnych szopach”, w Kondoa nauka odbywa się w „przestronnych salach jadalnych”, a w Koja „Nauka odbywa się w domach mieszkalnych opróżnionych na szkołę”.

Jak widać z powyższego - pisano - na ogół brak jest w osiedlach specjalnych budynków szkolnych, których władzom Brytyjskim nie udało się wybudować w roku ubiegłym. [...]. Obecnie jednak poczyniono już wszędzie przygotowania do budowy odpowiednich budynków szkolnych i najpóźniej do lipca sprawa będzie ostatecznie załatwiona. Nauczanie jest ogromnie utrudnione z powodu zupełnego braku podręczników szkolnych. Nauczycielstwu należą się więc wyrazy szczególnego uznania za pracę $\mathrm{w}$ tych trudnych warunkach. Spodziewamy się obecnie nadejścia transportu z podręcznikami z Jerozolimy. Wiemy również, że duży transport z pomocami szkolnymi, jak zeszyty, ołówki itp. jest już w drodze ${ }^{80}$.

W kolejnym (2) numerze w tekście Korespondencja $z$ osiedli przytoczono fragment listu z Tengeru mówiący o początkach szkolnictwa w tym osiedlu i jego stanie:

Kilkadziesiąt nauczycielek opracowuje wykłady z pamięci dla sześciu klas gimnazjalnych. Początkowo klasy mieściły się w domkach mieszkalnych, a nawet w kuchniach. Dzieci musiały przynosić ze sobą stoliki, a nawet pisać na kolanie. Obecnie większość ma już własne ołówki, zjawiły się nawet mapy. [...] Powstały gazetki ścienne. [...]. Bolączką naszych szkół w osiedlach jest brak podręczników ${ }^{81}$.

O tej ostatniej kwestii pisano też w ogólnym artykule Gtód ksiażki w tymże numerze. Odnotowano także przeistaczanie miejsc osiedlenia z obozów w osiedla, zmieniające swój wygląd zewnętrzny i tętniące życiem kulturalnym, którego ośrodkiem stawały się szkoły. W kontekście Masindi pisano, iż „Wielka to zasługa naszego nauczycielstwa i wychowawców, którzy brak materiału drukowanego zastępują wiernie zachowanym w pamięci skarbcem polskiego folkloru" ${ }^{82}$. W kolejnej części tego artykułu jego autor pisał: „Kiedy po upływie trzech miesięcy przyjechałem do Tengeru po raz drugi zastałem sytuację zmienioną nie do poznania. Na wzniesieniu górującym nad osiedlem powstał cały kompleks budynków szkolnych - już nie okraglaków, ale prostokątnych, przestronnych domów, w których pomieścić można całą klasę i sypialnię 40 łóżkową dla sierocińców”83. Przy zbliżającym się bilansie

\footnotetext{
80 „Polak w Afryce” 1943, nr 1, s. 2.

${ }^{81}$ Korespondencja $z$ osiedli, „Polak w Afryce” 1943, nr 2, s. 4.

82 J.Ch., Już nie obozy - ale osiedla, „Polak w Afryce” 1943, nr 2, s. 3.

${ }^{83}$ J. Ch., Już nie obozy ale osiedla, ciag dalszy, „Polak w Afryce” 1943, nr 3, s. 6.
} 
pierwszych ośmiu miesięcy tak, nie bez racji, podsumowywano ten okres: „W dziedzinie szkolnictwa, które objęło już swą siecią wszystkie osiedla, dokonano wszystkiego, co można było zrobić w obecnych warunkach" ${ }^{84}$. Relacjonujac w czerwcu 1943 r. warunki nauki w osiedlu Marandellas w Rodezji Południowej, pisano, iż bolączką szkoły jest tu brak odpowiedniego budynku, a lekcje odbywaja się w jadalni, co ogranicza czas nauki do przerw między posiłkami ${ }^{85}$. Gazeta relacjonowała kolejne postępy w warunkach pracy szkół i opieki nad najmłodszymi. I tak np. odnotowano ukończenie budowy (dwudziestu!) budynków szkolnych w Tengeru ${ }^{86}$, a potem ich uroczyste poświęcenie $^{87} \mathrm{z}$ towarzyszacym temu porankiem szkolnym zorganizowanym przez młodzież i nauczycieli z udziałem szkolnych chórów. W listopadzie $1943 \mathrm{r}$. omawiając m.in. osiedle w Masindi, pisano: „Do niedawna Masindi posiadało kilka sierocińców, rozrzuconych w kilku miejscach, co utrudniało pracę administracyjną i kontrolę. Niedawno wszystkie sierocińce przeniesiono do specjalnych zabudowań, skoncentrowanych w tzw. dziecięcej wiosce" 88 oraz że „W obu osiedlach w Koji i Masindi szkoły mieszczą się w specjalnych zabudowaniach. Nauczyciele pracuja z entuzjazmem nie tylko w dziedzinie nauczania, ale i w dziedzinie wychowawczej”. Z kolei w artykule Kidugala tętni życiem... w październiku 1944 r. pisano o wybudowaniu obszernego internatu dla dzieci w wieku szkolnym, co wiązało się z planowana rozbudową tego osiedla ${ }^{89}$. Kończąc niejako ten szkicowy zapis z „Polaka w Afryce” o warunkach pracy uczniów w różnych osiedlach, godzi się odnotować stwierdzenie z artykułu Opowieść o Kidugali, zamieszczonego w czerwcu 1945 r.: „[...] cała młodzież uczy się w warunkach zbliżonych do europejskich"90.

Wiele okazji do podniesienia tematyki młodych i najmłodszych dawały materiały prasowe poświęcone wizytacji osiedli uchodźczych przez ministra stanu i delegata Rządu RP na Wschodzie Henryka Strasburgera. Przykładowo pisząc o jego wizycie w osiedlu Masindi, Knake w obszernej relacji wiele miejsca poświęcił sierocińcowi i szkołom w tymże osiedlu ${ }^{91}$. Tak samo przy osiedlu Koja ${ }^{92}$. Tu autor m.in. pisał:

Ciagle odczuwa się wielki brak podręczników. Na całą klasę wypada zaledwie 8 podręczników do historii. [...]. Chwilami zupełnie zapominało się o Afryce. Na lekcjach przyrody mówiono o jeleniu i wiewiórce, na lekcji historii w jednej z klas szkoły

\footnotetext{
${ }^{84} \mathrm{Kn} .$, Przed bilansem ośmiu miesięcy..., s. 2.

${ }^{85} Z$ osiedli, „Polak w Afryce” 1943, nr 8, s. 3.

${ }^{86}$ Osiedla $w$ Tanganice, „Polak w Afryce” 1943, nr 15, s. 2.

${ }^{87}$ Poświęcenie budynków szkolnych w Tengeru, „Polak w Afryce” 1943, nr 26, s. 3.

${ }^{88}$ Rozwój osiedli w Ugandzie, „Polak w Afryce” 1943, nr 26, s. 4.

${ }^{89}$ M.H.P., Kidugala tętni życiem..., „Polak w Afryce” 1944, nr 39, s. 3.

${ }^{90}$ K. Skorska, Opowieść o Kidugali, „Polak w Afryce” 1945, nr 17, s. 5.

91 J. Knake, W Osiedlu Masindi, „Polak w Afryce” 1944, nr 11, s. 5; idem, W Osiedlu Masindi (cd.) „Polak w Afryce” 1944, nr 12, s. 3.

${ }_{92}$ Idem, W osiedlu Koja, „Polak w Afryce” 1944, nr 13, s. 3, 4.
} 
powszechnej nauczycielka opowiadała o królowej Bonie. Jedynie obce dźwięki mowy murzyńskiej, dolatujące z dachu naprawianego przez „czarnych ludzi” przypominały, że jesteśmy o tysiące mil od Polski ${ }^{93}$.

Po zakończeniu objazdu po polskich osiedlach minister Strasburger pożegnał się z młodzieżą specjalnie ku niej skierowaną odezwą opublikowaną na pierwszej stronie pisma 22 IV $1944 \mathrm{r}$.:

[...] proszę was raz jeszcze czytajcie jak najwięcej zarówno książek jak i gazetki, które do was dochodza, interesujcie się sprawami krajowymi, urządzajcie, jak to już nieraz czyniliście odczyty, kółka z dyskusją na tematy, które was interesują. Ja z mojej strony, w porozumieniu z Delegatami i Waszymi Opiekunami uczynię wszystko, co jest w mojej mocy, aby wam dostarczyć więcej książek, więcej pomocy naukowych i zapewnić możność nauki. O ile macie możność zainteresować się i zaznajomić z krajem, w którym mieszkacie, z jego przyroda, z jego geografia fauna i flora, to korzystajcie z tej sposobności ${ }^{94}$.

Nie zabrakło odniesień do młodych uchodźców w ogłoszonych w „Polaku w Afryce" spostrzeżeniach po wizytacji duszpasterskiej polskich osiedli przez ks. ppłk. dr. Reginka Wikariusza Generalnego Biskupa Polowego WP i ks. kpt. dr. Paulusa Kapelana WP w Jerozolimie. Istotne było tu to, iż obaj księża wizytatorzy nie skupiali się tylko na kwestiach religijnych, ale podkreślali także rozwijanie szkolnictwa zawodowego, co ma duże znaczenie dla odbudowy kraju po wojnie. Poza tym biorąc pod uwagę warunki klimatyczne wpływające na szybki rozwój fizyczny, zauważali, iż „Należałoby być może zwrócić większą uwagę na sporty i gimnastykę, wzorując się pod tym względem na szkolnictwie angielskim mającym znaczne doświadczenie w tym terenie" ${ }^{95}$. Nawiązując do tego ostatniego postulatu, godzi się przywołać materiał poświęcony otwarciu stadionu sportowego w Koji 1 X 1944 r. „Polak w Afryce” relacjonujacc to istotne dla osiedla wydarzenie, dał też dokładne sprawozdanie z zawodów sportowych, w których brała udział młodzież szkolna, relacjonując m.in., iż „W biegu na $60 \mathrm{~m}$. pierwsze miejsce w zespole żeńskim zdobyła uczennica klasy 6-ej Janina Smutkówna. W czasie 9.4 sekundy. W zespole męskim uczeń klasy 6-ej Emil Rekrut, w czasie 8.5 sekundy. W skoku w dal pierwsze miejsce w zespole żeńskim zajęła ucz. 6-ej kl. Franciszka Karczmarczykówna 3.75 m, w zespole męskim uczeń kl. 6-ej Lech Furst 4.15 m [...]"96.

$\mathrm{Na}$ marginesie trzeba zauważyć, iż o sprawach polskiego szkolnictwa pisano także w anglojęzycznej prasie, by przywołać tu tekst inspektora szkolnego Chruściela, pt. Szkolnictwo polskie we Wschodniej i Potudniowej Afryce, zamieszczony w dzienniku „The Rhodesia Herald” w marcu 1943 r.,

93 Ibidem, s. 3.

${ }_{94}$ Odezwa min. Strasburgera do młodzieży, „Polak w Afryce” 1944, nr 15, s. 1.

${ }_{95}$ Czyż-ski, Po wizytacji duszpasterskiej osiedli polskich w Afryce Wsch., „Polak w Afryce” 1944 , nr $14-15$, s. 4.

96 A. Milkner, Otwarcie stadionu sportowego w Koi, „Polak w Afryce” 1944, nr 39, s. 3-4. 
który został w polskiej wersji językowej opublikowany w numerze 1 „Polaka w Afryce" z 1944 r. Inspektor omawiając rozliczne trudności, tak podsumowywał szkolnictwo: „Zadziwiajace jest, że mimo tylu trudności i braków, dzieci opanowuja przepisany materiał, osiagając przeciętnie wymagany rozwój umysłowy i bardzo chętnie uczęszczają do szkoły. Wszystkie dzieci w wieku szkoły powszechnej pobierają naukę"97.

Bardzo wiele wzmianek lub nawet samodzielnych artykułów „Polak w Afryce” poświęcał udziałowi dzieci i młodzieży w życiu kulturalnym uchodźczej społeczności. Odnotowywano zarówno uczestnictwo w uroczystościach patriotycznych, religijnych, jak i różnego rodzaju wydarzenia kulturalne w postaci np. występów teatralnych lub wokalnych, czasem poświęcając im stosunkowo dużo miejsca. I tak np. w artykule Niezwykła delegacja pisano o występach „czterdzieściorga małych istot” (najmłodsze miały zaledwie trzy i pół roku!) z Tengeru na uroczystościach święta 3 Maja w Nairobi w 1943 r. Tak autor tekstu podsumowywał to wydarzenie:

Wśród uroczystości 3-majowych występ dzieci wysuną się na pierwsze miejsce. Zyskał nam w tych ciężkich chwilach, jakie przeżywamy ogólna sympatię. Wśród kłopotów i zgrzytów życia uchodźczego widok tych dzieci, pełnych radości a od najmłodszych lat przesiąkniętych tradycyjna kultura polska, napawał serca otuchą i wiara, że te przyszłe pokolenia, których przedstawiciele zabłąkali się na podzwrotnikowych obszarach Afryki potrafią kontynuować dzieło w tak tragiczny sposób przerwane przez wojnę $e^{98}$.

Jak zaznaczano w artykule, dzieci dały nie tylko trzy przedstawienia $\mathrm{w}$ teatrze, ale odwiedziły także ze spektaklem jeden ze szpitali, sprawiajacc tym dużą radość jego pacjentom.

\begin{abstract}
Rewelacją dla tutejszego społeczeństwa - pisano w innym artykule - były występy dzieci polskich w Nairobi, które pokazały na scenie nasze tańce i kostiumy regionalne. Występy te uprzytomniły również nam wszystkim jak wielką pracę wykonano w dziedzinie kulturalno-oświatowej, pomimo braku fachowych sił i wszelkiej pomocy naukowej. Dzieci z sierocińca w Tengeru, które oglądaliśmy w Nairobi, jak podbijały serca miejscowego społeczeństwa angielskiego, to były dzieci z naszych szkół uchodźczych, w których nauczyciel wykłada z pamięci, a dzieci uczą się czytać z „Polaka w Afryce", jak o tym świadczą listy nasyłane do redakcji ${ }^{99}$.
\end{abstract}

Relacjonując obchody Święta Niepodległości w 1943 r. w osiedlach Tanganiki i Ugandy, podkreślano udział w nich młodzieży, szkolne defilady, akademie i występy ${ }^{100}$. Samoistną wzmiankę poświęcono występom dzieci z osiedla

\footnotetext{
${ }_{97}$ Insp. Chruściel, Szkolnictwo polskie we Wschodniej i Południowej Afryce, „Polak w Afryce” 1944, nr 1-2, s. 2.

${ }^{98}$ Kn., Niezwykta Delegacja, „Polak w Afryce” 1943, nr 4-5, s. 4.

${ }_{99}$ Kn., Przed bilansem ośmiu miesięcy..., s. 2.

${ }_{100} 11$ listopada $w$ Tanganice $i$ Ugandzie, „Polak w Afryce” 1943, nr 27, s. 2.
} 
Koja w Kampali, gdzie 14 I 1944 r. prezentowały one wobec władz, w tym gubernatora, przedstawienie Jaś i Matgosia ${ }^{101}$. W obszernym artykule pt. Krasnoludki polskie $z$ Koji podbijaja Kampale powrócono do tych występów, stwierdzając już na wstępie, iż „Dzieci polskie z Koji - podbiły Kampalę tak, jak przed rokiem sierociniec z Tengeru zawojował Nairobi”"102. Dalej autor artykułu tak pisał o występach 69 dzieci z Koji: „Poziom gry tych maleństw liczących od lat 5-ciu do 15-tu, musimy to szczerze powiedzieć przewyższał wszystko czego moglibyśmy się spodziewać od naszych własnych dzieci”. W innym numerze odnotowano też jasełka wystawione przez 50-osobowa grupę dzieci z Marandellas i Digglefold w Salisbury ${ }^{103}$. Z kolei w listopadzie 1944 r. pisano:

Ośrodek szkolny „Krzyż Południa” w Oudtshoorn rozwinął żywą działalność na polu propagandy folkloru polskiego w Unii Pł. Afrykańskiej. Szkoła Powszechna im. św. Jadwigi utworzyła jeszcze w ubiegłym roku zespół taneczny, celem pielęgnowania tańców narodowych i chór międzyszkolny dla kultywowania pieśni polskiej. [...]. Zespół ten w liczbie 86 dzieci wzią udział w „Liberty Cavalcade” w Cape Town o czym miejscowa prasa pisała z dużym entuzjazmem. Ponadto urządził kilka pokazów tańca polskiego dla młodzieży szkół poł[udniowo] afrykańskich, dla studentów Wyższej Szkoły Wychowania Fizycznego, wreszcie dla nauczycieli szkół poł[udniowo] afrykańskich na Zjeździe Nauczycielstwa i w czasie Wystawy Szkolnej. [...]. Zespół taneczno-chóralny został ostatnio zaproszony do Johannesburga ${ }^{104}$.

Trzeba tu zaznaczyć, iż występy artystyczne nie były jedyną formą „wychodzenia na zewnątrz”. Jak bowiem pisał J. Brzeziński w swoim artykule o gimnazjum i liceum w Digglefold: „W salach «Women Institute» w Salisbury bywaja wystawy polskich haftów. Przez parę miesięcy dziewczęta w Digglefold pilnie haftuja, by wreszcie można oglądać wyniki ich pracy w formie masy narzutek, serwetek, zakładek, poduszek rozłożonych gustownie na stołach w dniu otwarcia wystawy. Mienią się tęczą barwne hafty"105.

„Polak w Afryce” odnotowywał też głosy prasy angielskiej o występach polskich dzieci. I tak np. zrelacjonowano „entuzjastyczne sprawozdania z występów dzieci polskich w stolicy Ugandy Kampali” ${ }^{106}$, gdzie wystawiono inscenizację bajki o królewnie Śnieżce i siedmiu krasnoludkach, a w przedstawieniu brało udział 60 dzieci, których wiek nie przekraczał 13 lat. Także przywoływane już przedstawienie Jaś i Małgosia ze stycznia 1944 r. zostało bardzo ciepło przyjęte na łamach „East. African Standard”, co odnotowano $\mathrm{w}$ polskiej gazecie ${ }^{107}$.

\footnotetext{
${ }^{101}$ Przedstawienie Jasia i Małgosi w Kampali, „Polak w Afryce” 1944, nr 4, s. 4.

102 „Polak w Afryce” 1944, nr 6, s. 3-4, artykuł podpisany Kn.

103 „Polak w Afryce” 1944, nr 7-8, s. 6.

104 „Polak w Afryce” 1944, nr 42, s. 3.

105 J. Brzeziński, Oaza młodości (zakończenie), „Polak w Afryce” 1945, nr 17, s. 5.

106 Przedstawienie polskich dzieci w Kampali, „Polak w Afryce” 1943, nr 4, 5, s. 4.

107 „Polak w Afryce” 1944, nr 5, s. 4.
} 
Na łamach „Polaka w Afryce” wielokrotnie publikowano teksty poruszające problematykę wychowawczą. I to w różnych kontekstach. Jednym z pierwszych takich materiałów był artykuł Możliwości i trudności zamieszczony w numerze 8 pisma z 1943 r. Przywołując rozliczne napotykane trudności, pisano:

Jedną z najważniejszych jest nie tylko brak podręczników, pomocy szkolnych i fachowych sił nauczycielskich, ale niemożność stworzenia w życiu naszych osiedli warunków, w których wpływ wychowawczy szkoły, harcerstwa i zorganizowanej własnymi siłami akcji oświatowej i wychowawczej przeważałby nad nie zawsze korzystnym oddziaływaniem najbliższego otoczenia. Niestety nosi ono często na sobie jeszcze wyraźne ślady przeżyć i strasznych warunków bytu minionego okresu, który najsilniejsze charaktery mógł wykoślawić, łamać ludzi fizycznie i moralnie. [...]. Dzieci z sierocińca wykazują o wiele większą dyscyplinę wewnętrzną od dzieci, które podlegają różnym wpływom, wśród których niestety nie zawsze przeważa wpływ celowej pracy wychowawczej ${ }^{108}$.

W tym też kontekście zwracano uwagę na możliwość zorganizowania dla tych dzieci internatów. „Internat byłby ideałem przynajmniej dla tych dzieci, które poza szkoła moga ulegać szkodliwym wpływom, dla dzieci, których temperament lub usposobienie wymagaja staranniejszej, ciagłej opieki i większej karności”. W artykule rozważano też możliwość kierowania najzdolniejszych dzieci znajacych język angielski do szkół angielskich, co dawałoby im pogłębienie znajomości tego języka. „Uwagi, które naszkicowaliśmy - pisano w zakończeniu artykułu - nie sa rezultatem oderwanych rozmyślań, lecz powstały wśród osób bezpośrednio stykających się z życiem naszych osiedli i pracujących w szkolnictwie. Byłoby pożądanym, aby sprawa ta nie znikła z łamów naszego pisma bez echa"109.

$\mathrm{Z}$ punktu widzenia prowadzonego przez nauczycieli, wychowawców i wszystkich pracujących z dziećmi i młodzieżą procesu ich „przywracania do życia" bardzo istotny był artykuł M.I. Ponikowskiej Wojna przeciwko dzieciom, omawiający (poza ogólnym obrazem losów dzieci polskich w czasie tej wojny) m.in. wyniki badań przeprowadzonych na grupie 1104 dzieci ze szkół junackich w Palestynie (które miały za soba pobyt w ZSRR), co można by odnieść do tej grupy wiekowej także i w Afryce: „Ogólne wyniki badań były następujące: $15 \%$ dzieci wykazało rozwój b. dobry, 36\% rozwój dobry, $42 \%$ średni i $17 \%$ cofnięcie intelektualne" ${ }^{110}$. Wskazywało to na konieczność szczególnego uwrażliwienia wszystkich majacych do czynienia z dydaktyka i wychowaniem.

W cyklu materiałów prasowych dotyczących kwestii wychowawczych trzeba też odnotować tekst dr. Wiktora Szaryńskiego U źódet charakteru, poruszający szereg ważnych z punktu widzenia wychowania młodzieży zagadnień.

\footnotetext{
108 K.e., Możliwości i trudności, „Polak w Afryce” 1943, nr 8, s. 1-2.

109 Ibidem, s. 2.

110 M.I. Ponikowska, Wojna przeciw dzieciom, „Polak w Afryce” 1943, nr 20, s. 3.
} 
Młodzież na uchodźctwie rośnie w wirze życia ułatwionego - pisał autor - Niemożliwość prawidłowego zorganizowania uchodźctwa ekonomicznie i społecznie stwarza konieczność przerzucania szeregu trosk zdrowej rodziny, jako komórki społecznej, na instytucje centralne. Młode pokolenie widzi ciagle „otrzymywanie” odzieży, pożywienia, zasiłków itp. W tych warunkach zamiast prawidłowej ambicji do walki o byt, do czynnej postawy wobec życia, zastępuje ją krytycyzm w stosunku do działania różnych instytucji, podejrzliwość, zgorzknienie, dopatrywanie się wszędzie nadużyć, protekcji, krzywdy ${ }^{111}$.

I choć może było to zbytnie wyostrzenie spojrzenia, W. Szyryński dotykał ważnego dla wychowania zagadnienia.

Mając na uwadze wszechstronny rozwój młodych uchodźców, zamieszczono też m.in. artykuł dr. Bronisława Frylinga, poświęcony roli muzyki w wychowaniu $^{112}$. Na marginesie trzeba zauważyć, iż z czasem w Tengeru otwarto szkołę muzyczna. Także np. w Kidugali obecna była edukacja muzyczna, o czym wspominano w niewielkim tekście Stoneczna Kidugala: „Ostatnio zaprowadzono tu naukę gry na fortepianie pod opieka fachowych sił. Do ćwiczeń, tak chętnie uczącej się muzyki młodzieży zakupiono specjalnie na ten cel pianino. Lekcje odbywają się w szkole"113.

Jednym z istotniejszych materiałów zamieszczonych na łamach „Polaka w Afryce" był artykuł L.K. Arnolda Zadania nauczycielstwa polskiego w Afryce, stanowiący niejako program tego środowiska. „Od nauczycieli, od rzetelności ich pracy zależy powstanie tej doprawdy «nowej», wymarzonej, wytęsknionej Polski. To jest najważniejsze zadanie polskiego nauczycielstwa $\mathrm{w}$ obecnej sytuacji. Pracę zacznijmy od doskonalenia samych siebie"114. W tym też kontekście autor, poza apelem o samokształcenie i przekazywanie doświadczenia kolegom po fachu, dawał m.in. wskazówki metodyczne co do prowadzenia np. lekcji pokazowych. Odnosząc się zaś do dzieci i młodzieży, pisał m.in.:

Dzieci nasze są dobre, na ogół bardzo grzeczne, nadspodziewanie pilne i nad wiek poważne. Starajmy się to wyzyskać. Szanujmy ich zdrowie, oszczędzajmy im wstrząsów nerwowych naprawdę pedagogicznym postępowaniem, nacechowanym miłością ku młodzieży, życzliwą pomocą i roztropnym wprowadzaniem do skarbca duchowego dorobku ludzkości. Nie przymykajmy jednak oczu na objawy ujemne. Wpływ materialistycznego, anormalnego otoczenia w czasach poprzedzajacych nasz przyjazd do Afryki pozostawił ślady w poglądach, słowach i zachowaniu się starszego społeczeństwa - może jeszcze nie zdajemy sobie z tego sprawy, ale wielkie. [...]. Prostujmy nastawienie materialistyczne młodzieży w kierunku idealizmu i bezinteresowności.

111 W. Szyryński, U źródet charakteru, „Polak w Afryce” 1944, nr 28, s. 3.

112 B. Fryling, Rola muzyki w wychowaniu, „Polak w Afryce” 1943, nr 30-31, s. 6.

${ }_{113}$ M.H.P., Stoneczna Kidugala, „Polak w Afryce” 1944, nr 30, s. 3.

${ }^{114}$ L.K. Arnold, Zadania nauczycielstwa polskiego $w$ Afryce, „Polak w Afryce” 1943, nr 18, s. 3. 
L.K. Arnold zwracał się też z apelem do nauczycieli, aby zachęcali młodzież do gromadzenia zbiorów przyrodniczych, które po wojnie można by przewieźć do Polski, by wykorzystać i w ten sposób czas pobytu w Afryce.

Na zagadnienia wychowawcze zwracano także uwage przy okazji rożnych kwestii. I tak np. w stałej rubryce „Smutne objawy na wesoło”, punktującej w lżejszy sposób różnego rodzaju nieprawidłowości w życiu społeczności uchodźczej, przestrzegano przed wciaganiem dzieci w rozgrywki starszych, podkreślając, iż mają one przede wszystkim się uczyć i kształcićc15.

Wychowanie młodego pokolenia, poza jego nauka, było jednym z priorytetów władz polskich. Nie bez kozery delegat MWRiOP, po ponad roku funkcjonowania szkolnictwa, w 1944 r. nakazał wizytatorom, dyrektorom, kierownikom i nauczycielom wszystkich typów szkół wnikliwie zainteresować się „stroną wychowawczą młodzieży zarówno w czasie obowiązkowej nauki szkolnej, jak i również życiem i zajęciami młodzieży w godzinach pozalekcyjnych"116. W związku z tym stwierdził, że wykazano dość duże braki i zaniedbania w tej dziedzinie. Wizytacje te, a także cele wychowawcze wyznaczone przez ministra WRiOP ks. Zygmunta Kaczyńskiego, wyłożone w czasie posiedzenia Rady Narodowej w Londynie 17 II 1944 r., stały się asumptem do ogłoszenia w październiku 1944 r. artykułu Wychowanie młodzieży pióra Seweryna Szczepańskiego. Mając na uwadze obie te kwestie, delegat podał w nim szereg wytycznych, których zastosowanie, jak pisał, „może znacznie ułatwić prawidłowe wychowanie”. Przede wszystkim należało sprawdzać, w jakich warunkach dziecko odrabia lekcje, przy czym w wielu wypadkach wskazane będzie zorganizowanie odrabiania lekcji w świetlicach szkolnych lub utworzenie samopomocy młodzieży w nauce pozaszkolnej. Należało także roztaczać opiekę nad organizacja zajęć pozaszkolnych, przy uzgadnianiu terminarza różnych imprez i zajęć, tak by ze sobą nie kolidowały. „Młodzież wdrażać należy do umiejętnego gospodarowania swoim czasem, a tępić chaotyczność i bezplanowość w pracy”. Delegat zwracał też uwagę na to, iż zawsze wartościowsze są te zajęcia, które młodzież organizuje sama, niż te, w których ,jest tylko biernym konsumentem rozrywek”. Podkreślał także rolę samorządu szkolnego w procesie wychowania i wdrażania do życia. Zwracał też uwage na usprawnienie akcji czytelnictwa. Nie pominął i kwestii zdrowotnych, a przede wszystkim zagrożenia malarią i przestrzegania przepisów antymalarycznych. Z powyższym tekstem korespondował ogłoszony w ostatnim z 1944 r. numerze artykuł W. Szyryńskiego Wychowanie $w$ walce o prawde, poświęcony kształceniu charakteru i wychowaniu dzieci117.

Nie zabrakło w „Polaku w Afryce” rozważań nad kształtem szkoły i procesu wychowawczego w przyszłej, odrodzonej Polsce. Przykładem tego może

\footnotetext{
115 „Polak w Afryce” 1943, nr 27, s. 2.

116 S. Szczepański, Wychowanie młodzieży, „Polak w Afryce” 1944, s. 5.

117 W. Szyryński, Wychowanie w walce o prawdę, „Polak w Afryce” 1944, nr 46-47, s. 6.
} 
być obszerny artykuł delegata MWRiOP S. Szczepańskiego, pt. Wychowanie $w$ Polsce Odrodzonej ${ }^{118}$, opublikowany w numerze 3 z 1944 r., dajacy asumpt do myślenia o tej kwestii środowisku nauczycielskiemu.

W kontekście działań wychowawczych można przywołać jeszcze swoisty apel zamieszczony w artykule Aktualna sprawa, w którym jego autor zwracał się do mieszkańców osiedli afrykańskich o zbieranie okazów fauny i flory pod kątem odbudowy zniszczonych w czasie wojny w Polsce zbiorów. „Zająć się tem może bez uszczerbku dla nauki w pierwszym rzędzie młodzież. Młodzieży naszej, która w czasie obecnej zawieruchy tyle dała i daje dowodów poświęcenia i ofiarności, nie trzeba chyba zachęcać do tej pracy"119. Jeśli już mowa o włączaniu młodzieży w różne akcje, można też odnotować jej udział w zorganizowanym w Kidugali „Tygodniu Zdrowia i Higieny”, o czym donosił „Polak w Afryce”. Celem owego przedsięwzięcia było wpojenie w mieszkańców osiedla, ,[...] że zdrowie ich zależy od przestrzegania czystości i stosowania się do szeregu wskazań lekarzy na których ciąży troska o zdrowie naszego uchodźctwa. Dlatego w czasie tygodnia "Zdrowia i Higieny» starano się wciagnać do pracy wszystkich a przede wszystkim młodzież" ${ }^{120}$, która czynnie w tym uczestniczyła, nie tylko w pochodzie, ale i zawodach sportowych oraz okolicznościowym widowisku Czystość - zdrowiem. Niewątpliwie aspekt wychowawczy miała też prowadzona w $1944 \mathrm{r}$. akcja pomocy dla mieszkańców Warszawy, którzy po upadku Powstania byli w obozie w Pruszkowie. Jak donosił „Polak w Afryce” z 15 X 1944 r., z osiedla w Tengeru w akcji tej „[...] żywy udział bierze młodzież szkolna. Uczennice klasy VII szkoły powszechnej $\mathrm{nr} 2$, nie mając funduszów własnych, a chcąc wziąć udział w ogólnej zbiórce samorzutnie zgłosiły się do robót polnych przy zbieraniu fasoli. Po tygodniowej pracy w godzinach pozaszkolnych dziewczęta zarobione shs. 100 - ofiarowały Komitetowi Pomocy dla Warszawy i Pruszkowa"121.

Jednym z ważnych elementów wychowania było wychowanie patriotyczne, które przejawiało się m.in. w różnego rodzaju obchodach świąt narodowych i akademiach z tym zwiąanych. Czytajac „Polaka w Afryce”, nieustannie można napotkać wzmianki o tego typu uroczystościach. Nie były one zreszta charakterystyczne tylko dla tej społeczności. Jak bowiem trafnie konstatowały, opisując to zjawisko po latach, autorki opracowania o Isfahanie:

Świętowaliśmy nieomalże do przesady każdą rocznicę, zachowywaliśmy każda tradycję, bez końca odbywały się akademie, ogniska, kominki, wieczory „ku czci” i „z okazji” - Mikołajki, Andrzejki, opłatki i święcone, powstania listopadowe, styczniowe, Trzeci Maj i Cud nad Wisła. Wszystko to było otoczone głębokim pietyzmem, wszystko było zawsze wyśpiewane i wydeklamowane z całego naszego młodego serca.

\footnotetext{
118 „Polak w Afryce” 1944, nr 3, s. 3-4.

119 A. Ciołek, Aktualna sprawa, „Polak w Afryce” 1944, nr 16, s. 4.

120 „Polak w Afryce” 1944, nr 31-32, s. 6.

121 „Polak w Afryce” 1944, nr 38, s. 3.
} 
Nikt z nas nigdy nie analizował, czy nie było tego przypadkiem za wiele - po grozie Rosji byliśmy szczęśliwi, że mogliśmy to robić. [...]. Nasze akademie były wyrazem tęsknoty, łatwiej ją było znieść wśród społeczności polskiej zjednoczonej narodową pieśnią i poezją ${ }^{122}$.

Oto jedna z bardzo wielu wzmianek o takiej działalności w osiedlach afrykańskich:

Państwowe Liceum i Gimnazjum w Tengeru urządziło uroczystą akademię w dniu Święta Niepodległości. W bogatym programie, na który złożyły się inscenizacje z „Sułkowskiego”, „Warszawianki” i „Przy biwaku”, deklamacje i śpiewy chóru szkolnego pod kier[unkiem] p. Jadwigi Marko, przedstawiały młodym słuchaczom i widzom polskie boje o niepodległość od bitwy racławickiej aż po walki Brygady Karpackiej, budząc w nich pragnienie i wolę pójścia „starym ojców naszych szlakiem” w walce o Wyzwolenie Polski ${ }^{123}$.

Inna wzmianka mówiła o tym, iż „Teatr szkolny Publicznej Szkoły Powszechnej w Bwana M'Kubwa urządził w Dzień Zaduszny wieczór dla uczczenia pamięci poległych żołnierzy polskich. Na program złożyły się deklamacje i śpiewy. W drugiej części wieczoru odegrano «Niebieski raport Wojciecha Zięby». Dochód przeznaczono na obrońców Warszawy i na internowanych w Pruszkowie” ${ }^{124}$. Tak zaś pisano o innej uroczystości w Kondoa: „W osiedlu tym 21 marca b.r. z okazji «Rocznicy Kościuszkowskiej» w miejscowej Świetlicy odbyła się Akademia. Na program złożyły się przemówienia, deklaracje [chyba deklamacje - M.N.K.] oraz pieśni wykonane przez chór szkolny"125.

Ważną rolę w życiu codziennym uchodźców odgrywała religia. Wielokrotnie też „Polak w Afryce” pisał o różnych uroczystościach religijnych i udziale w nich młodzieży. Informował też o Pierwszych Komuniach Świętych i bierzmowaniach, jak np. o udzieleniu sakramentu bierzmowania, przede wszystkim młodzieży szkolnej, 28 III 1944 r. przez ks. bp. Reesinga w osiedlu Koja ${ }^{126}$ oraz przez ks. bp. Edgara Maranta (wikariusza apostolskiego z Dar Es Salaam) w osiedlu Ifunda ${ }^{127}$.

„Polak w Afryce” odnotowywał ważne z punktu widzenia opieki nad młodzieżą wydarzenia, jak np. przybycie z Londynu do Nairobi S. Szczepańskiego, który obją stanowisko delegata MWRiOP ${ }^{128}$, lub jego wystapienie radiowe w audycji z Nairobi 2 X $1943 r{ }^{129} \mathrm{~W}$ pierwszym numerze z $1944 \mathrm{r}$.

\footnotetext{
${ }^{122}$ Isfahan miasto polskich dzieci, red. I. Beaupré-Stankiewicz, D. Waszczuk-Kamieniecka, J. Lewicka-Howells, Londyn 1988, s. XVII.

123 „Polak w Afryce” 1944, nr 43, s. 2.

124 „Polak w Afryce” 1944, nr 44, s. 3.

125 „Polak w Afryce” 1945, nr 12, s. 5.

126 „Polak w Afryce” 1944, nr 16, s. 4.

127 „Polak w Afryce” 1944, nr 30, s. 3.

128 „Polak w Afryce” 1943, nr 20, s. 1.

129 „Polak w Afryce” 1943, nr 21-22, s. 1.
} 
omawiając nowy rok radiowych audycji polskich nadawanych z Nairobi, zapowiedziano: „Większą uwagę zwrócimy na pogadanki z dziedziny przyrody a przede wszystkim wprowadzimy specjalne programy dla dzieci w godzinach przedpołudniowych. Będą to programy szkolne pomagające nauczycielom i wychowawcom, uzupełniajace jeszcze istniejące braki o ile chodzi o podręczniki i pomoce naukowe" 130 . W tym samym numerze podano komunikat Delegatury MWRiOP z dokładnymi informacjami o czasie tychże audycji.

Pismo było także forum, na którym pojawiały ważne dla procesu dydaktycznego ogłoszenia i komunikaty, by przywołać tu przykładowo Komunikat Delegatury MWRiOP zarządzajacy zorganizowanie we wszystkich szkołach powszechnych III stopnia, począwszy od początku nowego roku szkolnego, tj. 1 II 1944 r., klas VII oraz iż „Wszystkie dzieci, które ukończyły klasę szósta szkoły powszechnej, a nie przeszły do gimnazjum lub szkoły zawodowej, obowiązane są do uczęszczania do klasy siódmej szkoły powszechnej”"131.

W ramach sprawozdań $Z$ osiedli odnotowywano, chociaż nie zawsze, otwarcie lub zakończenie roku szkolnego, jak np. (aczkolwiek ze sporym opóźnieniem) 25 I 1945 r. pisano o zakończeniu w osiedlu Koja 30 listopada roku szkolnego: „W tym dniu odbyło się uroczyste nabożeństwo w czasie którego wygłosił kazanie do młodzieży Ksiądz Dziekan Słapa. Następnie odbyło się wręczenie świadectw szkolnych, zaś najlepsi uczniowie zostali obdarowani książkami”"132.

Redakcja pisma utrzymywała korespondencyjną więź z młodymi czytelnikami. I tak np. w numerze 13/14 w dziale „Odpowiedzi redakcji” przywołując zbiorowy list uczniów z Rusape, obiecywano pisać więcej o ich osiedlu ${ }^{133}$. Już w następnym numerze pisma opublikowano Korespondencje $z$ Rusape nadesłana przez uczniów klasy VII z tegoż osiedla. „W szkole uczymy się kroju i szycia. Mamy własną maszynę do pisania, na której jedna z pań nauczycielek przepisuje teksty z książek, z których się uczymy" ${ }^{134}$.

$\mathrm{W}$ reportażach $\mathrm{z}$ osiedli zwracano m.in. uwagę na odreagowanie przez dzieci trudnych przeżyć i ich „powrót do życia”. Między innymi w tekście Ze stonecznego Iranu nad jezioro Wiktoria A. Milkner zauważał: „Śmiech, ten najlepszy objaw zdrowia i radości życia słyszy się w Koji często. Zwłaszcza rozbawione i roześmiane dzieci każą choć na chwilę zapomnieć o gnębiących nas troskach" 135 .

Podsumowując niejako różne materiały prasowe poświęcone młodym i najmłodszym uchodźcom, warto przywołać jeszcze opinię Józefa Brzezińskiego,

\footnotetext{
${ }^{130}$ Nowy rok audycji polskich $z$ Nairobi, „Polak w Afryce” 1944, nr 1-2, s. 1.

${ }^{131}$ Komunikat Delegatury MWRiOP, „Polak w Afryce” 1944, nr 1-2, s. 4.

132 „Polak w Afryce” 1945, nr 3, s. 4.

133 „Polak w Afryce” 1943, nr 13-14, s. 6.

${ }^{134}$ Korespondencja $z$ Rusape, „Polak w Afryce” 1943, nr 15, s. 4.

${ }_{135}$ A. Milkner, Ze stonecznego Iranu nad jezioro Wiktoria, cz. 2, „Polak w Afryce” 1944, nr 34 , s. 3.
} 
harcmistrza, wizytatora Związku Harcerstwa Polskiego (ZHP), który po odwiedzinach ośrodka w Digglefold i wyrażeniu bardzo pochlebnej opinii o gen. Ferdynandzie Zarzyckim, dyrektorze tamtejszego gimnazjum i liceum, konstatował: „Innym zagadnieniem jest sama młodzież. Mocna. Silna pełna zapału i wiary w przyszłość, we własne ideały, w dobro i ważność czynionej pracy, żądna wiedzy - piękna, - wspaniała polska młodzież!"136. Dopełnieniem tej opinii były zdania z zakończenia tego artykułu:

Szeregi młodzieży dorastaja, kończą szkoły powszechne i stają się uczniami gimnazjów. [...]. Młodzież garnie się do nauki z zapałem, młodzież chce się uczyć! Ktoś mi niedawno mówił, że obecny pęd do nauki jest „moda”. Nie będę o to polemizował, ale stawiam tezę, że o ile jest nawet moda, to pożyteczną i dla sprawy nad wyraz cenna. Mało tego, należy uczynić wszystko możliwe, by modę tę podtrzymaćc ${ }^{137}$.

Jak już wspomniano, ogromną rolę w ,przywracaniu do życia” po przejściach w ZSRR młodego pokolenia odgrywało harcerstwo. Ono także znalazło swoje poczesne miejsce na łamach „Polaka w Afryce” i w różnych kontekstach obecne było w wielu numerach. Już w drugim numerze pisano: „Otwieramy w naszym piśmie nowy dział poświęcony naszemu harcerstwu we Wschodniej Afryce, w Ugandzie, w Tanganice i w Nyasslandzie. Pragniemy, aby dał on najpełniejszy obraz waszej pracy, waszych dążności, waszych myśli i uczuć" ${ }^{138}$. Tak też w tym samym numerze bardzo obszernie omówiono dwa pierwsze numery harcerskiego pisma „Głos harcerzy” wydawanego w Tengeru $^{139}$, a trzeci jego numer przedstawiono w kolejnym „Polaku w Afryce”140. Zamieszczono też ogólną informacje (wraz z danymi liczbowymi) o drużynach harcerskich w Masindi, Koja, Tengeru, Kondoa, Kidugali i Ifundzie. W jednym z kolejnych numerów opisano wydawane przez harcerzy w Kondoa pismo „Zza równika”141, obszernie relacjonując jego zawartość, a w innym „Czuj duch”, wydawane z kolei w Masindi ${ }^{142}$. Dopełniając ten wątek o wydawnictwach harcerskich, trzeba dodać, iż jeszcze w przedostatnim „Polaku w Afryce” z czerwca 1945 r. odnotowano wydanie pracy phm. Z. Słowikowskiego Cykle $Z_{\text {Zuchowe }}{ }^{143}$. W „Kronice harcerskiej” w sierpniu 1944 r. zamieszczono obszerna informację o trwającym od 26 czerwca do 5 lipca w Masindi centralnym Kursie Instruktorskim dla Hufców Harcerskich z Ugandy, a także dwudniowym Informacyjnym Kursie Harcerskim dla nauczycieli z Masindi obejmujacym genezę skautingu i historię ZHP, współpracę harcerstwa ze szkołą oraz

\footnotetext{
136 J. Brzeziński, Oaza młodości, „Polak w Afryce” 1945, nr 15-16, s. 7.

137 Idem, Oaza młodości, „Polak w Afryce” 1945, nr 17, s. 5.

${ }_{138} Z$ życia polskich harcerzy we Wschodniej Afryce, „Polak w Afryce” 1943, nr 2, s. 8.

139 N.K., Gtos harcerzy, „Polak w Afryce” 1943, nr 2, s. 8.

140 N.K., Harcerze polscy we Wschodniej Afryce, „Polak w Afryce” 1943, nr 3, s. 8.

${ }^{141}$ N.K., Harcerstwo polskie we Wschodniej Afryce, „Polak w Afryce” 1943, nr 6, s. 8.

${ }_{142}$ Czuj duch, „Polak w Afryce” 1943, nr 18, s. 4.

143 „Polak w Afryce” 1945, nr 18, s. 4.
} 
metodykę harcerską i zuchowa. Odnotowano też powołanie i zorganizowanie Hufca Harcerskiego w Koja ${ }^{144}$. W jednej z kolejnych edycji tejże „Kroniki” pisano też o kursie harcerskim nad jeziorem Duluti koło Tengeru, w którym uczestniczyło w sierpniu 1944 r. 90 osób, a także o analogicznym jak w Masindi kursie dla nauczycieli ${ }^{145}$. Śladem poprzednich informacji w październiku odnotowano trzeci już w Afryce Wschodniej (od 2 do 8 października) Centralny Kurs Harcerski z udziałem 81 uczestników z Kidugali, Morogoro i Ifundy ${ }^{146}$. W jednym $\mathrm{z}$ kolejnych numerów pisano:

\begin{abstract}
Harcerstwo ma niezwykle dodatni wpływ pod wszystkimi względami na młodzież, rozwijając w niej karność, zamiłowanie do pracy i nauki, i zachęcając ją do udziału w pracy społecznej osiedli. Prawie wszystkie dzieci szkolne należą do harcerstwa. [...]. Harcerze i harcerki zaczynają brać coraz żywszy udział w życiu osiedli w pracach referatów kulturalno-oświatowych itd. W niektórych osiedlach jak np. w Masindi biora udział w budowie kościoła, przygotowuja materiały opatrunkowe, gotuja bawełnę na watę itd. ${ }^{147}$
\end{abstract}

Jednocześnie zwracano uwagę na braki: „Harcerstwo Wschodnio Afrykańskie odczuwa przede wszystkim brak sportu, instruktorów, pism harcerskich”.

Relacje z przebiegu wizyty w różnych osiedlach ministra Henryka Strasburgera były także okazją do zaznaczenia obecności braci harcerskiej, jak np. przy wizytacji osiedla w Masindi, gdzie minister dokonał przeglądu harcerek i harcerzy, „którzy w liczbie kilkuset defilowali przed wzniesiona trybuną"148.

„Polak w Afryce” zamieszczał też informacje o kontaktach polskich i angielskich harcerzy. I tak np. w materiale Obóz harcerski angielsko-polski obszernie opisano wspólny obóz nad Jeziorem Wiktorii, niedaleko Kampali, który odbył się w sierpniu 1943 r. Jak relacjonował korespondent pisma: „Trzeba było przezwyciężyć liczne trudności. Musieliśmy zastosować się do naszych różnych obyczajów. Musieliśmy być cierpliwi wobec komplikacji i trudności językowych, ale jednak pogłębiliśmy wzajemne zrozumienie naszych odrębnych charakterów narodowych. Łaczyły nas te same, obowiazujące na całym świecie, hasła i prawa harcerskie"149.

Bardzo ważne dla rozwoju ruchu harcerskiego w Afryce było skierowanie tu z Bliskiego Wschodu ekipy instruktorskiej. O jej przybyciu do Nairobi poinformował czytelników w specjalnej notatce „Polak w Afryce” 4 VI 1944 r. ${ }^{150}$ Jednocześnie zamieszczono artykuł kierownika instruktorów

\footnotetext{
144 „Polak w Afryce” 1944, nr 29, s. 4.

145 „Polak w Afryce” 1944, nr 34, s. 3.

146 „Polak w Afryce” 1944, nr 40, s. 2.

${ }_{147}$ Harcerstwo Polskie w Wschodniej Afryce, „Polak w Afryce” 1943, nr 10, s. 3.

${ }^{148}$ Minister Stanu i Delegat Rzqdu RP dr Henryk Strasburger odwiedza osiedla Ugandy. $W$ osiedlu Masindi, „Polak w Afryce” 1944, nr 12, s. 2.

149 Obóz harcerski angielsko-polski, „Polak w Afryce” 1943, nr 18, s. 4.

${ }^{150}$ Ekipa harcmistrzów w Nairobi, „Polak w Afryce” 1944, nr 21, s. 3.
} 
dr. hm. W. Szyryńskiego Rozmowa z harcerzami. Jego autor w kontekście samorzutnego rozwoju harcerstwa w Iranie i w Afryce pisał tam m.in.:

[...] żyjemy w czasach, gdy czekająca nas pracę tylko wtedy zdołamy wykonać, gdy każdy zechce i potrafi pracować za kilku, gdy każdy pokaże, jak nie oglądając się na innych, własną drogą iść do wspólnego celu. Harcerze pokazali wiarę we własne siły i swą postawę muszą rozwijać dalej, opierając o tę cechę mocny i prawy charakter. [...]. Mocna walka i twardy trud tworzą pogodne życie. Spodziewam się więc spotkać tutaj wiele głęboko pogodnych oczu. Liczę na to, że dzięki temu się porozumiemy. I liczę bardzo na szczerą pomoc w naszej pracy nad pogłębieniem w tym afrykańskim gronie polskich harcerek i harcerzy ${ }^{151}$.

Nie było to zreszta jedyne wystapienie W. Szyryńskiego na łamach tego pisma. Wszystkie jego teksty skierowane przede wszystkim do harcerzy miały głęboki wydźwięk dydaktyczny i wychowawczy, jak np. ten $O$ nowy, lepszy świat ${ }^{152}$ czy przywoływany już w niniejszym artykule materiał $U$ źródet charakteru.

Na łamach „Polaka w Afryce” wielokrotnie gościł hm. Józef Brzeziński, z przybyłej do Afryki ekipy instruktorów. I tak np. w swoich reminiscencjach ogłoszonych po pobycie w osiedlu Bwana M’Kubwa J. Brzeziński zwracał uwage na rolę harcerstwa $\mathrm{w}$ wychowaniu młodego pokolenia ${ }^{153}$. Z kolei w tekście Victoria Falls relacjonując swoją podróż inspekcyjna, przedstawiał harcerstwo działające w Livingstone ${ }^{154}$.

Dzień chyli się ku końcowi - pisał w zakończeniu artykułu - Słońce dotyka swą tarczą wierzchołków drzew. Harcerze pilnie gromadzą drzewo na ognisko, a gdy ostatnie promienie skryły się za horyzontem, pierwsze języki płomienia zaczęły ogarniać nagromadzony chrust. Z piersi siedzących w krag harcerzy wyrywa się pieśn - „Płonie ognisko i szumią knieje”. A potem inne, ludowe, żołnierskie, harcerskie - a echo łapie tony i roznosi je hen daleko po buszu. I dziwią się potężne baobaby, kłujące akacje, dziwi się wysoka ostra trawa. Przecież do tej pory słuchały tylko rytmicznych dźwięków murzyńskiego tam-tam. A z daleka huczy potężny wodospad!155

Brzeziński zachęcał do poznawania otaczającego harcerzy świata poprzez organizowanie wycieczek. Jego tekst Wycieczki harcerskie, opublikowany w listopadowym numerze pisma, był nie tylko zachęta, ale jednocześnie precyzyjnie podanym materiałem instruktażowym dla kierowników takich „leśnych” wypadów ${ }^{156}$. Owe wycieczki poza celem ściśle wychowawczym pozwalały ich uczestnikom na bezpośrednie „dotykanie” afrykańskiej przyrody. Ten aspekt był zresztą obecny niejako od początku, bowiem już w numerze 6 „Polaka

\footnotetext{
${ }^{151}$ W. Szyryński, Rozmowa z harcerzami, „Polak w Afryce” 1944, nr 21, s. 3.

${ }^{152}$ Idem, „O nowy, lepszy świat”, „Polak w Afryce” 1944, nr 29, s. 3.

153 J. Brzeziński, Bwana M’Kubwa (zakończenie), „Polak w Afryce” 1944, nr 40, s. 3.

${ }^{154}$ Idem, Victoria Falls, „Polak w Afryce” 1944, nr 41, s. 3.

155 Idem, Victoria Falls (zakończenie), „Polak w Afryce” 1944, nr 42, s. 4.

${ }^{156}$ Idem, Wycieczki harcerskie, „Polak w Afryce” 1944, nr 44, s. 4.
} 
w Afryce” ogłoszony został (z zaznaczeniem, iż tylko dla harcerzy) konkurs „Co wiemy o słoniu?” ${ }^{157}$, z przesłaniem „Uczmy się patrzeć”, czyli poznawać otaczający nas świat zwierząt.

Analogicznie jak przy udziale uczniów w różnego rodzaju uroczystościach i obchodach świąt, zawsze odnotowywano obecność na nich i harcerzy, jak np. w materiale Obchód 3-go Maja w Osiedlach, gdzie m.in. pisano: „W osiedlu Ifunda, podobnie jak gdzie indziej po uroczystym nabożeństwie odbyła się defilada harcerzy, którzy sprawiali jak najlepsze wrażenie [...]"158.

Trzeba jeszcze dodać, iż poza informacjami tekstowymi o harcerzach na łamach „Polaka w Afryce” publikowano szereg zdjęć dokumentujących harcerskie dzieje na Czarnym Lądzie. I tak np. w numerze 3 pisma zamieszczono fotografie „Harcerki polskie w Afryce” ${ }^{159}$, tak samo przy okazji wizyty ministra H. Strasburgera, gdy ten przyjmował defiladę harcerzy ${ }^{160}$.

W lipcu 1945 r. ukazał się ostatni numer „Polaka w Afryce”, co było bezpośrednią konsekwencją uznania przez mocarstwa zachodnie władz warszawskich i tym samym cofnięcia uznania dla Rządu RP działającego w Londynie. W dziejach uchodźców otwierało to kolejny okres ich tułaczych losów.

Jak można wnosić z przeglądu zawartości „Polaka w Afryce” pod kątem młodych i najmłodszych uchodźców, z jednej strony jako odbiorców pisma, $\mathrm{z}$ drugiej zaś strony jako obiektu jego zainteresowania, gazeta ta poświęcała im wiele miejsca.

Niezwykle ważne w procesie dydaktyczno-wychowawczym było podjęcie inicjatywy wydawania specjalnego pisemka dla młodych w postaci „Płomyczka Afrykańskiego” oraz dodatku „Książka Polska na Uchodźctwie” stanowiącego, wobec braku podręczników i polskich książek, ogromna pomoc w nauczaniu.

Publikowane na łamach „Polaka w Afryce” w różnej formie i objętości materiały pozwalały na w miarę całościowy ogląd tej młodej i najmłodszej społeczności. Dzięki temu mieszkańcy odległych osiedli mogli nie tylko dowiadywać się o szkołach i inicjatywach szkolnych w innych osiedlach, ale także konfrontować swoje $\mathrm{w}$ tym względzie działania $\mathrm{z}$ osiagnnięciami $\mathrm{w}$ innych ośrodkach.

Wiele miejsca, i słusznie, w tych szczególnych warunkach poświęcono na zagadnienia związane $\mathrm{z}$ nauczaniem i wychowaniem. Pisano o osiagnięciach w tym względzie, ale i dostrzegano słabości oraz zagrożenia. Doceniając rolę harcerstwa w kształtowaniu postaw i charakterów, nie zaniedbano i tego wątku tematycznego. Poza ogólnymi opisami wielokrotnie przywoływano bardzo konkretne dane liczbowe pozwalające odbiorcom na ujrzenie skali udziału młodej społeczności w codziennym życiu uchodźców w Afryce. Generalnie

\footnotetext{
157 N.K., Harcerstwo polskie we Wschodniej Afryce, „Polak w Afryce” 1943, nr 6, s. 8.

158 Obchód 3-go Maja w Osiedlach, „Polak w Afryce” 1943, nr 6, s. 4.

159 „Polak w Afryce” 1943, nr 3, s. 4.

160 „Polak w Afryce” 1944, nr 12, s. 2.
} 
rzecz ujmując, materiały zamieszczane w „Polaku w Afryce” stanowią ważne dopełnienie wytworzonej w latach wojny dokumentacji, a także powstałych w czasach późniejszych relacji i wspomnień.

\section{Streszczenie}

Uchodźcy polscy z ZSRR, którzy w latach II wojny światowej dotarli na kontynent afrykański, rozlokowani zostali w krajach Brytyjskiej Afryki Wschodniej (tj. w Kenii, Tanganice i Ugandzie) oraz w Rodezji Północnej i Rodezji Południowej, a także w Unii Południowej Afryki. W latach 1943-1945 w Nairobi ukazywała się polska gazeta pt. „Polak w Afryce”. Fakt, iż blisko połowę uchodźców stanowili młodzi i najmłodsi, wpłynął na zainteresowanie nimi redakcji pisma. Artykuł ukazuje, co i w jakiej formie pisano o młodych uchodźcach. Przede wszystkim zamieszczano materiały dotyczące szkolnictwa, życia kulturalnego, harcerstwa. Bardzo dużo miejsca poświęcano zagadnieniom wychowawczym. Materiały prasowe stanowią istotne dopełnienie bazy źródłowej do badania losów najmłodszych uchodźców, którzy w latach 1942-1945 przebywali w Afryce.

\section{Pole in Africa on the Young and Youngest Polish Refugees from the USSR in Africa in 1943-45}

The Polish refugees from the USSR who reached the African continent during the Second World War were quartered in the countries of British East Africa (i.e. in Kenya, Tanganyika, and Uganda), in Northern Rhodesia and Southern Rhodesia, as well as in the Union of South Africa. In 1943-45, in Nairobi, a Polish newspaper entitled Polak w Afryce (Pole in Africa) was published. The fact that nearly half of the refugees were young and the youngest children, often orphans or half-orphans, made the magazine's editors interested in them. The article presents what and in what form was written about the young refugees and published in the Polish paper. First of all, it were texts on education, cultural life, and scouting. A lot of space was devoted to educational issues. Press materials make a significant supplement to the source base for research into the fate of the youngest refugees who lived in Africa in 1942-45.

\section{Bibliografia}

Chmielewski W., Polska administracja szkolna w latach 1944-1950, Piotrków Trybunalski 2010. Chmielewski W., Powstanie delegatur polskiej administracji szkolnej na uchodźstwie, „Rozprawy z Dziejów Oświaty" 2012, t. XLIX, s. 35-53.

Chmielewski W., Szkolnictwo polskie w Afryce Środkowo-Wschodniej i Południowej podczas II wojny światowej, „Przegląd Historyczno-Oświatowy” 2008, nr 3-4, s. 61-74.

Hejczyk A., Sybiracy pod Kilimandżaro. Tengeru. Polskie osiedle w Afryce Wschodniej we wspomnieniach jego mieszkańców, Rzeszów-Kraków 2013.

Isfahan miasto polskich dzieci, red. I. Beaupré-Stankiewicz, D. Waszczuk-Kamieniecka, J. Lewicka-Howells, Londyn 1988.

Ney-Krwawicz M., Na pięciu kontynentach. Polskie dzieci, młodziė̇ $i$ szkoły na tułaczych szlakach 1939-1950, Warszawa 2014.

Ney-Krwawicz M., „Polak w Iranie” o młodych i najmłodszych uchodźcach polskich z ZSRR w Iranie w latach 1942-1944, „Dzieje Najnowsze” 2014, nr 1, s. 85-110. 
Pancewicz B.M., Harcerstwo w Afryce 1941-1949, Londyn 1985.

Pietrzak J., Polscy uchodźcy na Bliskim Wschodzie w latach drugiej wojny światowej. Ośrodki, instytucje, organizacje, Łódź 2012.

Polskie sybiraczki harcerki w Afryce 1942-1950, oprac. H. Dąbkowski, Warszawa 2002.

Wróbel E., Wróbel J., Rozproszeni po świecie. Obozy i osiedla uchodźców polskich ze Zwiazku Sowieckiego 1942-1950, Chicago 1982.

Wróbel J., Uchodźcy polscy ze Zwiazku Sowieckiego 1942-1950, Łódź 2003.

Wróbel J., Z Syberii na Antypody. Osiedle polskich sierot w Oudtshoorn 1943-1950, w: Wokót spraw trudnych, bolesnych i zapomnianych. Studia i szkice, red. E. Kowalczyk, L. Ladorucka, W. Marciniak, B. Szubtarska, J. Żelazko, Łódź 2014, s. 863-907.

Zins H., Polacy w Afryce Wschodniej, Lublin 1978.

Marek Ney-Krwawicz (ur. 1956) - prof. dr hab., pracownik Instytutu Historii Polskiej Akademii Nauk. Zainteresowania naukowe koncentruje głównie wokół problematyki Polskiego Państwa Podziemnego ze szczególnym uwzględnieniem Armii Krajowej. Drugim polem zainteresowań są losy młodego pokolenia Polaków i ich szkół poza granicami Kraju w latach 1939-1950. Z tej tematyki opublikował syntezę Na pięciu kontynentach. Polskie dzieci, młodzież $i$ szkoty na tułaczych szlakach 1939-1950 (Warszawa 2014). Autor wystawy „Polskie dzieci, młodzież i szkoły na tułaczych szlakach 1939-1948” prezentowanej w Oddziale Instytutu Pamięci Narodowej w Gdańsku, Muzeum Wojska w Białymstoku, Muzeum Niepodległości w Warszawie. E-mail: mney-krwawicz@ihpan.edu.pl.

Marek Ney-Krwawicz (b. 1956) - prof. dr hab., employee of the Tadeusz Manteuffel Institute of History, Polish Academy of Sciences. His research interests focus mainly on the subject of the Polish Underground State, with particular emphasis on the Home Army. The second field of his interest is the fate of the young generation of Poles and their schools abroad in 1939-50. The author of a synthesis on this subject, Na pięciu kontynentach. Polskie dzieci, młodzież $i$ szkoty na tułaczych szlakach 1939-1950 (Warsaw 2014); and the author of the exhibition on the similar subject: 'Polish Children, Youth and Schools on wandering trials 1939-48' presented at the Gdańsk Branch of the Institute of National Remembrance, the Army Museum in Białystok, the Museum of Independence in Warsaw. E-m ail: mney-krwawicz@ihpan.edu.pl. 